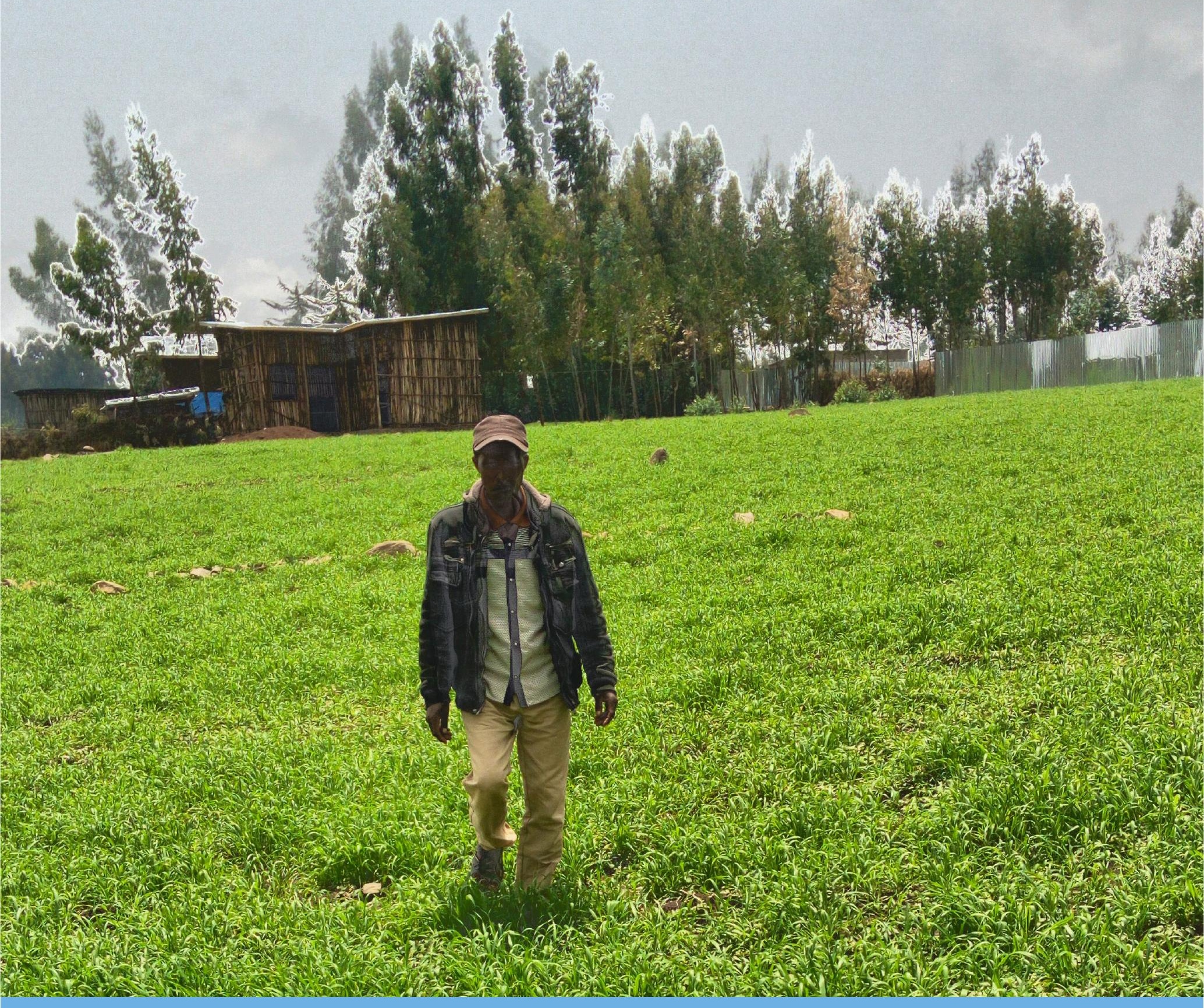

Status of Introduction and Distribution of Fodder Seeds and Planting Materials in Selected Districts of Amhara, Oromia, SNNP and Tigray Regional States

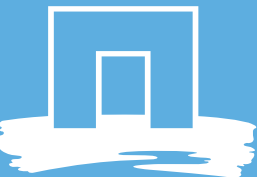





\section{Status of Introduction and Distribution of Fodder Seeds and Planting Materials in Selected Districts of Amhara, Oromia, SNNP and Tigray Regional States}


Tolera, A., Vernooij, A., Berhanu, T., 2019. Status of Introduction and Distribution of Fodder Seeds and Planting Materials in Selected Districts of Amhara, Oromia, SNNP and Tigray Regional States. Wageningen Livestock Research, Report 1152.

This report can be downloaded for free at https://doi.org/10.18174/471450 or at www.wur.nl/livestock-research (under Wageningen Livestock Research publications).

(C) 2019 Wageningen Livestock Research

P.O. Box 338, $6700 \mathrm{AH}$ Wageningen, The Netherlands, T +31 (0)317 4839 53,

E info.livestockresearch@wur.nl, www.wur.nl/livestock-research. Wageningen Livestock Research is part of Wageningen University \& Research.

All rights reserved. No part of this publication may be reproduced and/or made public, whether by print, photocopy, microfilm or any other means, without the prior permission of the publisher or author.

Wageningen Livestock Research is NEN-EN-ISO 9001:2015 certified.

All our research commissions are in line with the Terms and Conditions of the Animal Sciences Group. These are filed with the District Court of Zwolle.

Wageningen Livestock Research Report 1152 


\section{Table of contents}

$\begin{array}{ll}\text { List of Tables } & 5\end{array}$

$\begin{array}{ll}\text { List of figures } & 6\end{array}$

$\begin{array}{ll}\text { List of Abbreviations and Acronyms } & 7\end{array}$

$\begin{array}{ll}\text { Executive Summary } & 9\end{array}$

$\begin{array}{llr}1 & 1 \text { Introduction } & 11\end{array}$

$2 \quad$ Background on improved forage production in Ethiopia 13

2.1 Species of forage crops and agro-ecological adaptations 13

$\begin{array}{lll}2.2 & \text { Forage seed production associate challenges } & 14\end{array}$

$\begin{array}{ll}2.3 \text { Adoption of improved forage technology } & 14\end{array}$

3

$\begin{array}{ll}\text { Methodology } & 15\end{array}$

$\begin{array}{lll}3.1 & \text { Study areas } & 15\end{array}$

3.2 Selection of respondents $\quad 15$

$\begin{array}{ll}3.3 & \text { Preparation for the assessment } \\ 3.4 & 16\end{array}$

3.4 Assessment questions and types of data collected 16

$\begin{array}{llr}4 & \text { Main Finding of the Study } & 17\end{array}$

$\begin{array}{lll}4.1 & \text { Importance of livestock production } & 17\end{array}$

4.2 Trends in livestock production and productivity 18

$\begin{array}{ll}4.3 & \text { Livestock production constraints } \\ & 18\end{array}$

$\begin{array}{lll}4.4 & \text { Livestock feed supply situation } & 20\end{array}$

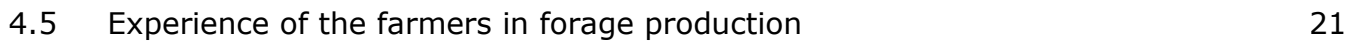

4.5.1 Tigray region $\quad 22$

$\begin{array}{ll}4.5 .2 \text { SNNPR } & 23\end{array}$

4.5.3 Amhara Region 23

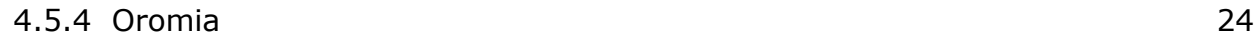

4.6 Introduction and distribution of fodder seeds and planting materials $\quad 25$

4.6.1 Actors involved in supply of forage seed and/or planting materials $\quad 25$

4.6.2 Preconditions set to qualify for receiving the forage seeds and/or planting materials

4.6.3 The type and amount forage seed or planting material distributed 27

4.6.4 Area of land planted to improved forage crops 29

4.6.5 Criteria for selection of the species of forage crops grown 31

4.6.6 Preparations made before distribution and establishment of the forage $\begin{array}{ll}\text { crops } & 32\end{array}$

4.6.7 Current area of planted forage owned by the farmers 32

$\begin{array}{lll}4.7 & \text { Adequacy of the amount of forage produced } & 33\end{array}$

4.8 Purchase of additional feed from outside 34

4.9 Selection of forage seeds and planting materials $\quad 35$

4.10 Management of the established fodder crops. 35

4.11 Utilization and importance of improved forage crops 35

$\begin{array}{ll}4.12 & \text { Sustainability issues }\end{array}$ 
5.2 The way forward

Appendix 1 Questionnaire to Assess Introduction and Distribution of Fodder Seeds and Planting Materials 


\section{List of Tables}

Table $1 \quad$ List of recommended forage species for the different agro-ecologies of Ethiopia 3

Table 2 Districts and kebeles selected for the assessment 5

Table $3 \quad$ Livestock holding per household of the respondents in Degem district

Table $4 \quad$ Livestock holding per household of the respondents in Tiyo district 8

Table $5 \quad$ Livestock holding per household of the respondents in Shashemene district 8

Table 6 Types forage seeds and planting materials distributed to the different districts and kebeles 19

Table $7 \quad$ The types and amount of forage seeds and planting materials distributed in Eastern and 22

\begin{tabular}{ll} 
South Eastern zones of Tigray Regional State \\
\hline Table $8 \quad$ The types and amount of forage seeds and planting materials distributed in Fogera district of 22
\end{tabular}

\begin{tabular}{ll} 
Amhara Regional State \\
\hline Table 9
\end{tabular}

Table $9 \quad$ The types and amount of forage seeds and planting materials distributed in Dale and 22 Shebedino districts of Sidama Zone, SNNPR

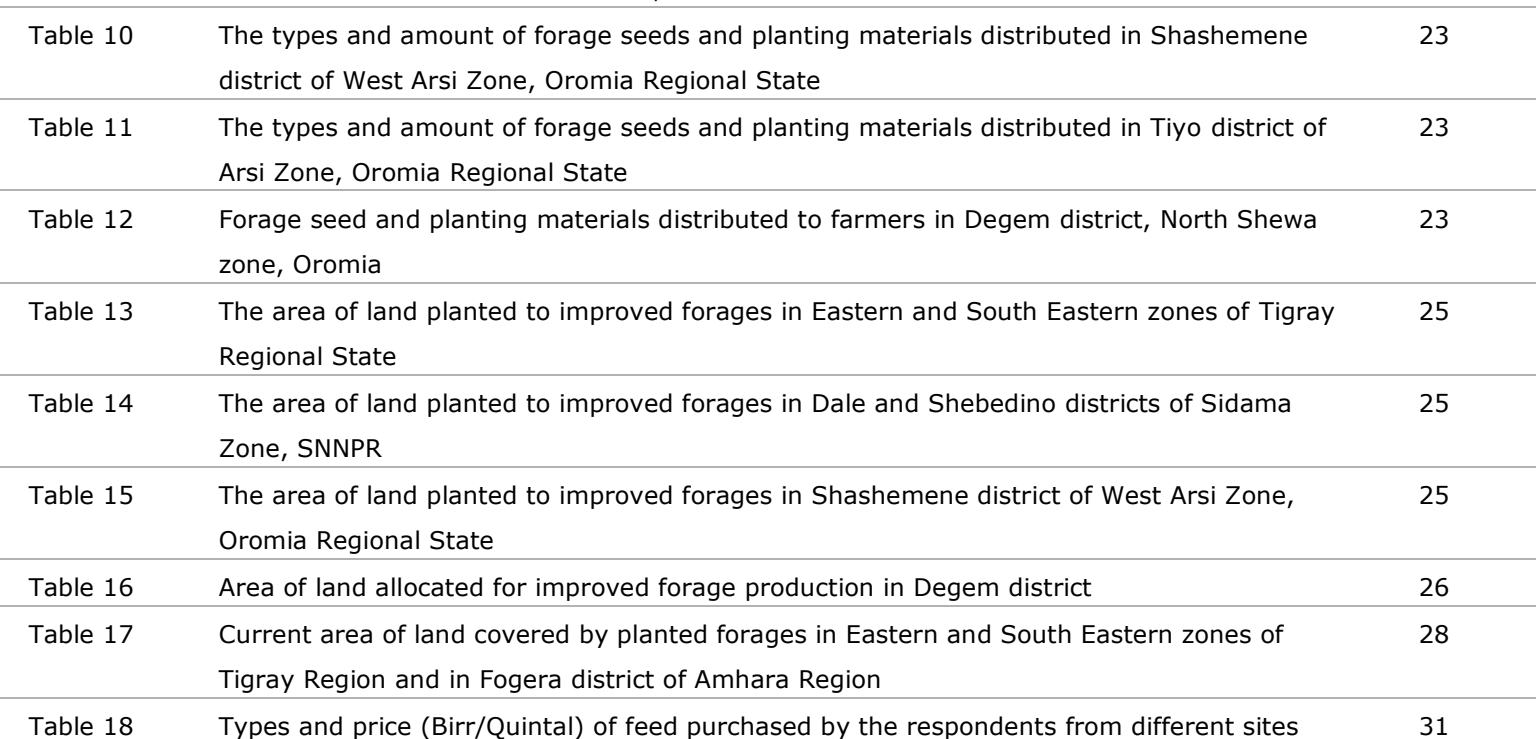




\section{List of figures}

Figure 1 Percentage of farmers reporting prior experience in the production of certain types of forage

crops in the four districts of South Eastern and Southern Zones of Tigray Regional State

Figure 2 Percentage of farmers reporting production of different forage crops in Dale and Shebedino

24 district of Sidama Zone, SNNPR

Figure 3 The area of land planted to improved forages in Fogera district of Amhara Regional State

Figure $4 \quad$ Percentage of farmers purchasing different types of feeds in Tigray regional state 


\section{List of Abbreviations and Acronyms}

ACDI/VOCA

\begin{tabular}{l}
\hline AI \\
\hline ARDU \\
\hline BRIDGE \\
\hline CIAT \\
\hline DairyBISS \\
\hline DA \\
\hline DPU \\
\hline E.C. \\
\hline EDGET \\
\hline EIAR \\
\hline FTC \\
\hline GIZ \\
\hline ILRI \\
\hline NGO \\
\hline OSRA \\
\hline REST \\
\hline SLM \\
\hline SNNPR \\
\hline SNV \\
\hline UR \\
\hline ACDIVOAA
\end{tabular}

Agricultural Cooperative Development International/ Volunteers in Overseas Cooperative Assistance

Artificial insemination

Arsi Rural Development Unit

Building Rural Income through Inclusive Dairy Business Growth in Ethiopia

International Center for Tropical Agriculture

Dairy Business Information Service and Support

Development agent

Dairy Processing Unit

Ethiopian calendar

Enhancing Dairy Sector Growth in Ethiopia

Ethiopian Institute of Agricultural Research

Farmers Training Center

The Deutsche Gesellschaft für Internationale Zusammenarbeit (German International

Cooperation)

International Livestock Research Institute

Non-governmental organization

Oromo Self Reliance Association

Relief Society of Tigray

Sustainable land management

Southern Nations, Nationalities and Peoples Region

Netherlands Development Organization

University and Research 


\section{Executive Summary}

Livestock production is an important economic activity serving as a means of employment and livelihood for millions of Ethiopians. However, productivity of the livestock sector is very low due to several constraints. Shortage of feed and low quality of the available feeds have often been cited as the main constraints. As a result, the performance of livestock in terms of growth rate, milk production, body weight gain and reproduction is much below the potential and the country is net importer of dairy products.

The major feed resources available in the country are crop residues and natural pastures, which are characterized by low nutritional quality. Availability of good quality concentrates and cultivated forages is insignificant. The current assessment focused on the forage seeds and planting materials distributed by SNV EDGET Project in Amhara, Oromia and SNNP Regions as well as similar distributions made by Mekelle University ad Tigray Bureau of Agriculture and Natural Resources. The purpose of the assessment was to get a good overview of the results of the seed distribution activities and to learn from the experiences for future follow up activities in a bid to improve the supply of good quality forage crops for dairy farmers.

The importance of livestock production was rated very high and high by most respondents in all the four regions. In all study sites, cattle were reported to be the most important species of animals kept by the farmers with increasing proportion of crossbred cattle in the herd. The overall trend shows that the number of local cattle is decreasing whereas the number of crossbred cattle is increasing. However, shortage of feed and low quality of the available feeds were cited as critical constraints affecting productivity of livestock.

The types and quantity of forage seeds/planting materials distributed to farmers and the area of land planted varied from place to place and from farm to farm depending on agro-ecology, area of land owned, livestock holding (which reflects demand for feed), and awareness and commitment of individual farmers. The quantity of seed given to individual farmers varied from 0.5 to $40 \mathrm{~kg}$ whereas the area of land planted to improved forage was in the range of $20 \mathrm{~m} 2$ to 10 ha but most of it varies within the range of $100 \mathrm{~m} 2$ and 0.5 ha.

At the end of the project, some farmers have expanded their forage production activities as means producing good quality feed for their animals and as a means of income generation through sale of forage seeds and/or planting materials. On the other hand, some farms reported a declining trend in the area of land planted to forage crops, which might be related to difficulty of getting sustainable supply of forage seeds/planting materials after the termination of the EDGET project or due to mere lack of motivation when the project support is not in place. Some farmers reported their readiness to continue with the production of the improved forage even after the termination of the project. Continuity would be much easier for forage crops multiplied by cuttings. Propagation by cuttings is much easier than use of seeds as the technique is more easily mastered by the farmers than the latter.

Overall, although some farms have expanded the planting of forage crops, sustainability of the intervention appears to be questionable in many cases. Free distribution of forage seeds by NGOs and government contributes to underdevelopment of the forage seed system. Sustainability depends on awareness of the farmers, availability of seeds/planting materials and dependable market linkage for forage/forage seed and livestock products. The farmers generally need continuous follow up for technical support and market linkage to be actively involved in cultivated forage and/or forage seed production. 


\section{Recommendations for future action}

1. Future forage development interventions should give more focus to forage crops that combine high yield potential with good nutritional quality to simultaneously address the problems of feed shortage and low quality of available feeds.

2. The government and development partners should give due attention and the necessary policy, technical and capacity building support for smallholder farmers and private sector actors interested in commercial forage and forage seed production

3. The smallholder farmers could be engaged in forage seed production and marketing either individually or organized into seed producers groups.

4. Creating market linkages for smallholder seed producers or linking the smallholder seed producers with commercial seed producers in out grower scheme for multiplication of forage seed on smallholder farms.

5. Providing training and the necessary technical support to the farmers to build their awareness and skills in improved forage production.

6. Arrangements for provision of basic and foundation seed would be necessary to ensure sustainable seed supply. In this respect, regional, national and international agricultural research centres working on forage crops could play important roles in basic seed supply, which can be linked with interested private sector seed producers for multiplication of the basic seeds to be used as a source of foundation seed.

7. Government institutions and NGOs should stop providing free handout of forage seeds. Instead they may provide limited subsidy or partial financing to absorb the initial high cost of forage seeds through cost sharing arrangement with the farmers or seed producers.

8. The government is also expected to create favourable conditions for forage seed producers to access credit service or bank loan and to develop a seed certification system to ensure the quality of the seed being marketed. 


\section{Introduction}

The Dairy Business Information Service and Support (DairyBISS) project is a project that started operation in 2015 to stimulate private dairy sector development in Ethiopia. The project is implemented by Wageningen University \& Research (UR) Livestock Research and partners in Ethiopia and aims at increasing the number of profitable farms and firms in the Ethiopian dairy sector.

Ethiopia is a livestock and potential dairy country. Livestock production has significant economic and social importance at household level and makes significant contributions to the national economy. However, the productivity and economic contribution of livestock is much below the potential due to various constraints. Shortage of feed supply in terms of both quantity and quality is often cited to be one of the main constraints limiting the realization of exploitation of the full potential of the livestock resources of the country. When animals are not properly fed, they cannot express their genetic potential for production and reproduction. The performance of the Ethiopian livestock resources in terms of growth rate, milk production, body weight gain and reproduction is much below the potential. The country is net importer of dairy products as it could not produce sufficient milk for domestic consumption.

In smallholder mixed crop-livestock productions systems, livestock feed supply is mainly dependent on crop residues, natural pastures, and other agricultural by-products. But the predominant feed resources, crop residues and natural pastures, have low nutritional quality. The availability and supply of good quality feeds (concentrates and cultivated forages) are quite insignificant. Improved forages could provide useful nutrients especially in the rural areas where access to agro-industrial by-products is a problem.

Although Ethiopia has experience of about five decades of forage research and development, the adoption rate and utilization of improved forages for livestock feeding has been very low. Difficulty of accessing suitable seeds or planting materials is often being cited as one of the challenges hindering expansion of forage production and use. However, recently there is increasing trend of private sector (including private entrepreneurs, farmers or pastoral cooperatives, youth groups, and individual smallholder farmers or pastoralists) interest and engagement in forage and forage seed production and marketing.

As one of the strategies to improve the feed resource base for dairy cattle in Ethiopia, Government departments and non-governmental organizations (NGOs) have been distributing significant volumes of fodder seed and planting materials to different parts of the county. Whilst the demand and need for such inputs is beyond doubt, there is no clarity about the success rate of these distribution activities. There are good indications about improved availability and efficient utilization of fodder on dairy farms, as well as indications of unsuccessful establishment practices, improper management of the fodder and inadequately utilizing the fodder in dairy rations.

In line with this, a project funded by the Dutch government and implemented by Netherlands Development Organization (SNV) known as Enhancing Dairy Sector Growth in Ethiopia (EDGET) project supplied dairy farmers with forage seeds and supported them to produce and use different types of forages in recent years. In addition, reports also indicate that the EDGET project promoted various models of decentralized forage seed production through Farmers Training Centers (FTCs) and farmer groups. Similar distribution was made by Tigray Bureau of Agriculture and Natural Resources and Mekelle University in Tigray region. In order to get a good overview of the results of the seed distribution activities and to learn from the experiences for future follow up activities, a study was commissioned by the DairyBISS project to look into the experiences and success rates of the introduction of improved fodder seed on dairy farms in parts of Ethiopia to be used as a base for future intervention in the upcoming Building Rural Income through Inclusive Dairy Business Growth in Ethiopia (BRIDGE) Project. 


\section{Objective}

The objectives of the study were:

- To assess the preconditions and processes of forage seed distribution, establishment, management and utilization of the established forage on dairy farms

- To assess the trends in forage production and feed availability following the project intervention as well as sustainability of the intervention. 


\section{Background on improved forage production in Ethiopia}

Sustained availability of the desired quantity and quality of animal feed and proper feeding management make the foundation of livestock production systems. Cultivated forage and pasture crops provide useful nutrients especially in rural areas where availability and accessibility to agroindustrial by-products is a problem. Combined use of cultivated forages with genetically improved animal gives benefits of increasing feed conversion efficiency leading to increased livestock productivity and reduction of green house gas emissions which would serve as a base towards achieving attainment of food and nutrition security and climate resilient green economy.

\subsection{Species of forage crops and agro-ecological adaptations}

Various forage development strategies that address the needs of both smallholder farmers and specialised large-scale forage producers have been developed and suitable species for each strategy have been recommended for the different agro-ecologies in Ethiopia. For smallholder farmers with problems of land shortage, options like integration of food and forage crops are highly suitable. In areas with problems of soil fertility and soil degradation, forage crops can suitably be planted on soil bands, soil conservation structures, as hedge and alley crops. On the other hand, highly productive and quality forage crops such as alfalfa, elephant grass, cowpea, lablab, vetch etc. are suitable in wellorganized intensive production systems with better production inputs and irrigation to supply quality feed for highly productive livestock such as dairy cattle. In this situation, it is worthwhile to assess the opportunity cost of using the available land for forage versus crop production.

Table 1 List of recommended forage species for the different agro-ecologies of Ethiopia.

\begin{tabular}{|c|c|}
\hline Forage species & Adaptations \\
\hline Avena sativa (Oats) & High to mid altitude \\
\hline Pennisetum purpureum (Elephant, Napier grass) & Low to mid altitude \\
\hline Pennisetum pedicellatum (Desho grass) & Low to high altitude \\
\hline Panicum maximum (Guinea grass) & Low to high altitude \\
\hline Melinis minutiflora (Molasses grass) & Low to mid altitude \\
\hline Sorghum Sudanese (Sudan grass) & Low to mid altitude \\
\hline Vicia dasycarpa (Vetch) & High to mid altitudes \\
\hline Trifolium spp, (annuals \& perennials clovers) & High to mid altitude \\
\hline Melilotus altisimus & High to mid altitude \\
\hline Lotus maizeiculatus (Birdsfoot trefoil) & High - altitude \\
\hline Medicago sativa (Lucerne, Alfalfa) & High to low altitude \\
\hline Lablab purpureus (Lablab) & Mid to low altitude \\
\hline Vigna unguiculata (Cowpea) & Mid to low altitude \\
\hline Desmodium intortum (Green leaf Desmodium) & Mid to low altitudes \\
\hline
\end{tabular}




\begin{tabular}{ll} 
Desmodium uncinatum (Silver leaf Desmodium) & Mid to low altitude \\
\hline Stylosanthes spp (Stylo) & Mid to low altitude \\
\hline Macroptilium atropurpureum (Siratro) & Mid to low altitude \\
\hline Browse Trees & High altitude \\
\hline Chamaecytisis palmensis (Tagasaste, Tree Lucerne) & Mid to low altitude \\
\hline Gliricidia sepium (Gliricidia) & Mid to low altitude \\
\hline Cajanus cajan (Pigeon pea) & Mid to low altitude \\
\hline Calliandra callothyrsus(Calliandra) & Mid to low altitude \\
\hline Leucaena leucocephala (Leucaena) & Mid to low altitude \\
\hline Sesbania sesban (Sesbania) & \\
\hline Root crops & High altitude
\end{tabular}

Source: (EARO, 2000; Tolera et al., 2012)

\subsection{Forage seed production associate challenges}

Seed production of forage crops is a complex process because different forage crops require different agronomic practices, special techniques of harvesting, threshing, and seed processing. Although forage seeds can be produced by smallholder farmers on small plots of land, more successful seed production is made by large-scale forage seed enterprises at selected sites with skilled personnel and modern production and processing facilities. Annual forage crops require relatively simple management practices for seed production and exhibit higher productivity compared to perennial ones. Moreover, seed processing such as threshing and cleaning for most of the perennial species are difficult and require special skills and knowhow. Seed productivity of most perennial forage grasses and herbaceous forage legumes is in a range of $100-400 \mathrm{~kg} / \mathrm{ha}$. Contrary to cereal and other food crops, so far there is no established private or public forage seed production and marketing system in Ethiopia, which makes the forage seed system virtually nonexistent.

\subsection{Adoption of improved forage technology}

In spite of the critical shortage and low quality of the available feed resources, the adoption of improved forage production and utilization is extremely low in Ethiopia due to various factors. There could be many reasons for such poor adoption rate of improved forage crops (FAO, 2004). However, it is believed that the potential for adoption of improved forages could be high when and where market oriented livestock production is possible and improved animals (crossbred) respond to improved feeding. Farmers may readily accept improved forage production and feeding management if the return on investment is attractive. Thus, forage production and utilization in feeding systems must go hand in hand with market oriented livestock production and efficient marketing of livestock and livestock products. 


\section{Methodology}

\subsection{Study areas}

Two study areas were selected.

a. One of the areas was planned to overlap with areas where SNV EDGET project was actively involved in forage seed and planting materials distribution. This activity focused on establishing sustainable forage seed exchange among dairy farmers and enhancing household level fodder production. The EDGET project aimed at establishing and strengthening forage seed grower group in each of their intervention districts. In addition, individual households were supported in backyard forage production at least on $100 \mathrm{~m} 2$ to produce different forages (i.e. grasses, legumes species and fodder beets) for use on their farms to feed their animals. The assessment was carried by trained enumerators selected from DairyBISS trained advisors and from among the former SNV EDGET project dairy promoters because of their prior knowledge of the kebeles where the study was conducted.

b. The second area of the project was in Tigray region where Mekelle University and Tigray Bureau of Agriculture and Natural Resources were involved in distribution of fodder seeds and planting materials. A total of 32 farmers were interviewed from this category from Eastern and South Eastern Zones of the Tigray Regional State. The field assessment for this component was carried out by staff members of Mekelle University and Tigray Bureau of Agriculture and Natural Resources. The zones, districts and kebeles included in assessment are listed in Table 2.

Table 2 Districts and kebeles selected for the assessment.

\begin{tabular}{|c|c|c|c|}
\hline Region & Zone & District & Kebeles \\
\hline \multirow{2}{*}{ Amhara } & Awi & Dangila & Gargie \& Bacha Berayit \\
\hline & East Gojjam & Awabel & Enebi \& Yekeyit \\
\hline \multirow[t]{4}{*}{ Oromia } & Arsi & Tiyo & Haro Bilalo \& Tullu Kuche \\
\hline & East Shewa & Ada'a & Ude \& Dhankaka \\
\hline & \multirow[t]{2}{*}{ North Shewa } & Degem & Ano Degeme \& Ana Jiru Bisadimo \\
\hline & & Kuyyu & W/Gose \& H/Cheri \\
\hline \multirow{3}{*}{ Tigray } & Eastern Tigray & Hawzen & Debrebirhan \& Siluh \\
\hline & \multirow[t]{2}{*}{ South Eastern zone } & Enderta & Didiba \& Arato \\
\hline & & Hintalo-Wajirat & Adigudom \& Hewane \\
\hline
\end{tabular}

\subsection{Selection of respondents}

In general, the study was conducted on 120 households located in 15 districts and 10 zones of the four major regions of the country. Two kebeles were selected from each district and from each kebele 4 household heads were interviewed. In addition, one key informant, representing the experts at the district level, was interviewed from each district. 


\subsection{Preparation for the assessment}

Before commencement of the field assessment, discussions were held with SNV staff member who was leading the EDGET project forage seed distribution activities to get an idea about the process. Then assessment tools (questionnaires and checklists) were developed and a one day start up workshop was conducted to train and orient the data collectors on importance of fodder development initiative for livestock sector development issues as well as regarding the need for the assessment, type of data to be collected and how to carry out the data collection. After completion of the data collection, two days of data summary workshop was conducted.

\subsection{Assessment questions and types of data collected}

Preparation for fodder seed distribution activities: The aims and modes of implementation of fodder seed distribution activities were assessed by interviewing the parties involved in these projects. The assessment included the following issues, among others.

- Criteria used for selection of target beneficiaries or farmers. Based on the criteria the farmers to whom the fodder seeds and planting materials were distributed were identified.

- Type of fodder and amount of fodder seed/planting material distributed to each recipient farmer were assessed.

- Criteria for deciding on the type (species) of fodder seed or planting material given to each farmer were identified.

- Methods applied to raise the awareness of the farmers and the advice given on fodder establishment and management were also assessed.

Establishment of fodder with distributed seeds: Assessment were made as to how much of the distributed seeds were actually established as fodder crops and how much is still available on the concerned farms. The amount of seed distributed determines the acreage that could theoretically be planted. Efforts were also made to determine if the amount of forage seed distributed corresponded to the area of land planted to improved forages, however, the response obtained in this respect was not very clear to draw conclusion regarding the discrepancy observed between the amount of seed distributed and the actual amount of forage established on the farm. In addition, the condition and growth performance of the established fodder crops were assessed grossly and qualitatively in order to get an idea of how well they are performing and how promising they are.

Management of the established fodder crops: Different varieties of fodder crops require different management practices such as land preparation, soil fertilization, weeding, cutting or cropping frequency and techniques. The farmers were also interviewed on their current management practices of the established fodder plots.

Utilization of the established forage: Farmers were interviewed on utilization of the fodder focusing on specific uses of the fodder; feeding including utilization of the fodder in dairy cow feeding rations but also for other possible purposes. This assessment also included method of utilization whether green chopping or cut-and-carry feeding, feeding alone or mixing with other feeds and their overall perception regarding the importance and utilization of fodder crops.

Sustainability issues: The farmers were interviewed whether the area of their forage land has either increased or decreased after the initial establishment with the support of the project. They were also asked about their future plan for forage production after the end of the project. 


\section{Main Finding of the Study}

\subsection{Importance of livestock production}

The importance of livestock production was rated very high and high by most respondents in all the four regions. Nearly $90 \%$ of the respondents in Oromia, Amhara and SNNPR regions rated the importance of livestock production very high or high. For example, all farmers in Degem district reported the importance of livestock to be high (50\%) or very high (50\%). The average livestock holding of the respondents in this district was reported to be 15.3 head of cattle (including calves), 19.1 sheep, 3.3 donkeys (range $1-6$ ) and 10.3 chickens.

Table 3 Livestock holding per household of the respondents in Degem district

\begin{tabular}{|c|c|c|c|c|}
\hline Animals & \multicolumn{2}{|l|}{ Local } & \multicolumn{2}{|c|}{ Crossbred } \\
\hline \multicolumn{5}{|l|}{ Cattle } \\
\hline Cows & 1.2 & $1-2$ & 3.4 & $2-6$ \\
\hline Bulls/Oxen & 1.3 & $1-2$ & 3.4 & $2-6$ \\
\hline Calves & - & & 1.9 & $1-3$ \\
\hline \multicolumn{5}{|l|}{ Sheep } \\
\hline Ewes & 9 & $5-15$ & - & - \\
\hline Chicken & 4.3 & $2-7$ & 6 & $3-11$ \\
\hline
\end{tabular}

Majority of the cattle (about $96.7 \%$ ) owned by the respondents are crossbred animals. In all study sites, cattle are the most important species of animals kept by the farmers with increasing proportion of crossbred cattle in the herd. In general, cattle, sheep, donkeys and chicken are the main animals kept by the farmers (Tables 3,4 and 5). The overall trend shows that the number of local cattle is decreasing whereas the number of crossbred cattle is increasing.

The respondents asserted that livestock production is important as a means of income generation through the sales of animals and animal production. The crossbred cattle are important for milk production as a means of income source and for consumption by the family. Sheep production is important as means of income generation through sale of the animals. Donkeys play vital role as means of transport. The farmers also keep some number of local and crossbred or exotic chickens. However, their proportion was relatively lower in Tigray region.

Table 4 Livestock holding per household of the respondents in Tiyo district.

\begin{tabular}{|c|c|c|c|c|}
\hline Animals & \multicolumn{2}{|l|}{ Local } & \multicolumn{2}{|l|}{ Crossbred } \\
\hline \multicolumn{5}{|l|}{ Cattle } \\
\hline Cows & $2.13 \pm 0.93$ & $1-4$ & $2.8 \pm 0.98$ & $1-4$ \\
\hline Bulls/Oxen & $3.75 \pm 1.20$ & $2-6$ & $3.5 \pm 1.12$ & $2-5$ \\
\hline Horses & $1.5 \pm 0.5$ & $1-2$ & & \\
\hline
\end{tabular}




\begin{tabular}{lllll} 
Donkeys & $1.88 \pm 0.6$ & $1-3$ & & \\
\hline Chicken & $10 \pm 0$ & $10^{*}$ & $36 \pm 24.6$ & $8-88$ \\
\hline
\end{tabular}

*Only 1 farmer

Table 5 Livestock holding per household of the respondents in Shashemene district.

\begin{tabular}{|c|c|c|c|c|}
\hline Animals & \multicolumn{2}{|l|}{ Local } & \multicolumn{2}{|l|}{ Crossbred } \\
\hline \multicolumn{5}{|l|}{ Cattle } \\
\hline Cows & $2 \pm 1.41$ & $1-5$ & $5 \pm 6.78$ & $1-20$ \\
\hline Bulls/Oxen & $2 \pm 1$ & $1-4$ & $3.67 \pm 3.09$ & $1-8$ \\
\hline Calves & $1.67 \pm 0.47$ & $1-2$ & $1.5 \pm 0.76$ & $1-3$ \\
\hline Donkeys & $1.5 \pm 0.21$ & $1-3$ & & \\
\hline Chicken & $7.3 \pm 3.82$ & $1-12$ & & \\
\hline
\end{tabular}

Overall, dairy cows are highly valued for production of milk that is used for consumption at home and for sale to generate income for various family expenses such schooling of children. Oxen and equine are highly valued as sources of draught power for land preparation and as means of transport, respectively. Livestock are also sources of manure that can be used as organic fertilizer to improve soil condition and fertility for improved crop yield. In some cases, manure is also used as a source of fuel either as dried cow dung or to generate biogas that can be used for heating and cooking.

\subsection{Trends in livestock production and productivity}

The respondents indicated that the number of local cattle, sheep, goats, horses, mules and local chicken is showing a decreasing trend whereas the number of crossbred cattle and hybrid or exotic chicken is showing an increasing trend. However, the number of donkeys was reported to be about the same with some respondents reporting a decrease and others reporting an increase while a large number reporting neither an increase nor a decrease. About $34.4 \%$ of the respondents from Tigray region keep two or more crossbred cows, two of the respondents (6.3\%) keep 15 or more cows while one respondent (3.1\%) from the Region keep 39 crossbred cows.

Regarding productivity of animals, it was indicated that the crossbred animals have higher performance in terms of milk yield, growth rate, and body weight gain during fattening as well as in reproductive performance if given adequate and good quality feed and good management. Age at first calving for local cows was reported to be about 4 years whereas that of crossbred cattle was indicated to be about 2 years to 2 and a half. Similarly the local cows have longer calving interval of about 2 years while the crossbred cows can calve at about one year interval. The crossbred animals have higher production and reproduction performance if properly fed and managed. However, if they are not given adequate supply of good quality feed and if they are not properly managed they may have difficulty even to survive leave alone production. In addition, some observations were reported where the production and reproduction performance of the local cattle showed very significant improvements with improvements in their feeding and management. For example, a typical exception of a properly managed and well fed local heifer reaching puberty or sexual maturity at one year of age was reported.

\subsection{Livestock production constraints}

Livestock production is an important agricultural activity in all the study sites. Accordingly all the respondents keep variable number of different species of livestock. However, the performance of the 
livestock resources is much below the potential because of several challenges constraining productivity and economic contribution of livestock. Some of the main constraints are listed as follows.

1. Feed scarcity - both in quantity and quality. Feed scarcity is the main critical problem hampering productivity of livestock. This was reflected by almost all respondents in all the four regions. The overall feed supply was reported to be inadequate to feed the livestock population and the quality of the available feed resources is also low that does not meet the nutritional requirements of the animals. The available feed resources are dominated by poor quality crop residues and overgrazed pastures characterized by low content of essential nutrients and energy, high fiber content and low digestibility. The production and utilization of cultivated and improved forage crops is very much limited. Thus, currently the contribution of cultivated forage crops to the overall feed supply is very insignificant. Without adequate supply of good quality feeds, animals will have low production and reproduction performance and as the quantity and quality of feed further deteriorates even survival of the animals would be at stake leave alone production. Most of the interviewed farmers buy-in additional feed from outside but none of the farmers reported selling feed to other farmers.

2. Shortage of land for grazing or feed production. This problem was cited as a major constraint affecting livestock production because of its impact on feed availability. There is stiff competition between crop and livestock production in this regard. The area of land under crop production is increasing from time to time to produce more crops for the continuously increasing human population at the expense of grazing land. The expansion of cropping also diminishes the area of land available for cultivated forage production.

3. High cost of purchased feed. Rural farmers do not have easy access to agro-industrial by-products and compound feed (concentrate feed) and when farmers buy feed from outside to offset the shortage of on-farm production and availability, very often the price is very high and prohibitive as it is beyond what the farmers can afford. This is exacerbated by the scattered settlement of the smallholder farmers, difficulty of accessing transport facilities and high transportation cost. Most of the respondents (>90\%) reported that they buy-in additional feed to supplement the ration of their animals. Most of the purchased feeds include agro-industrial by-products (e.g. noug cake, wheat bran), grass hay and in rare cases forage crops such as oats and Desho grass. The farmers mostly buy-in additional feed during the dry season whereas very few farmers reported that they buy supplementary feed throughout the year.

4. Market problem for livestock products. The main challenge in this respect is the low price of milk and high price of production inputs, particularly feed. This is a serious problem in more remote rural areas with poor road access and far away from urban centres and milk collection and processing facilities. Seasonality of milk market, particularly lack of market during the long fasting season of the Orthodox Christians, is a serious problem hampering profitability of dairy farming in Ethiopian highlands.

5. Low adoption rate of improved forage production. Despite shortage of feed supply, efforts to produce high quality improved forage crops was reported to be low in most of the areas covered by the assessment. A number of interrelated factors were mentioned as causal factors for such low adoption rate. These include shortage of land and competition for land with crop production, lack of proper awareness and knowhow as well as unavailability of forage seeds. There is a general notion of prioritizing cereal and vegetable production over forage crops and tendency of allocating only marginal areas for forage production.

6. Shortage of clean drinking water for livestock as well as shortage of water for use for irrigation to produce irrigated forage production in situations where rainfall is not dependable for grass and cultivated forage production.

7. Inadequate livestock extension service. It was reported that most of the time the livestock extension agents are assigned to do either crop or natural resources related extension activities instead of livestock extension. This could be due to either lack of allocation of the necessary resources needed for livestock extension or the extension supervisors at the district and kebele levels are mostly from either crop or natural resources background with little or no focus on or understanding of the need for livestock extension.

8. Diseases and parasites. Health problems such as mastitis and bovine tuberculosis (TB) are common problems in most dairy farms. Lack of drugs and veterinary service hampers timely treatment of the animals. In some circumstances, there is a problem of drug resistance due to indiscriminate or inappropriate use of some drugs.

9. Poor management practices practiced by farmers e.g. housing 
10. Genetic problem and poor AI service. Difficulty of accessing bull or efficient artificial insemination (AI) service for crossbreeding and genetic improvement was cited by most respondents as one of the major challenges, particularly for the dairy sub-sector. Local animals are characterized by low genetic potential for milk and meat production. In addition, although there is huge variability among local animals in their milk and meat production potential, such potentials have not been properly exploited due to absence of record keeping and lack of rigorous selection and breeding programs as well as inadequate feeding and management practices.

11. Financial constraints. Some farmers reported that financial constraints are prohibitive to invest in modern productivity improving livestock technologies such as purchase of feed and improved breeds of animals.

\subsection{Livestock feed supply situation}

In all the districts where the assessment was carried out, there was a trend of decreasing availability of grazing land and declining feed supply. However, in the kebeles targeted for forage seed and planting materials distribution and production, it was reported that there were improved forage production activities.

\section{SNNPR, Sidama Zone}

Dale and Shebedino districts of Sidama zone - There are encouraging activities of forage adoption and production in these districts. Farmers engaged in forage production are generating substantial income from fodder and planting materials sale in addition to alleviating their livestock feed problem. The farmers in these districts are particularly more interested in perennial forage crops that are propagated by cuttings or splits such as elephant grass (Pennisetum purpureum), desho grass (Pennisetum pedicellatum) and Guatemala grass and those forages whose seed production and collection are relatively easy such as pigeon pea and cowpea.

\section{Amhara Region}

Dangila district - There is good performance of improved forage production in the district with particular focus on Rhodes grass production. Some farmers have advanced to the level of producing and selling forage seed. Farmers that have adopted improved forage production have reported improvements in milk production and body condition of their animals. Furthermore, it was reported that improved forage production is currently being scaled out from model farmers to other farmers in the district. On the other hand, the district is showing intermediate performance in terms of adoption of Desho and elephant grass production while the adoption of production of forage legumes is relatively low.

Fogera district - The production of annual forage crops predominates in the district. In addition, perennial forages such as elephant grass and Desho grass are also being tried.

Awabel - Different forage crops such as oats, vetch, elephant grass, Desho grass, alfalfa, Sesbania, cowpea and Setaria are produced in the district. The area of land allocated for forage production in the district is about $0.63 \pm 0.42$ ha with a range of $0.07-1.16$ ha.

\section{Oromia}

Because of significant variation in agro-ecology, the types of forage crops grown in Oromia region vary from place to place. However, some of the most common forage crops grown in many places include Elephant grass (Pennisetum purpureum), Desho grass (Pennisetum pedicellatum), Rhodes grass (Chloris gayana), Oats (Avena sativa), vetch (Vicia dasycarpa), cow pea (Vignia unguiculata), lablab (Lablab purpureum), pigeon pea (Cajanua cajan), alfalfa (Medicago sativa), Leucaena (Leucaena leucocephala), Sesbania (Sesbania sesban) and tree lucerne or tagasaste (Chaemacytisus palmensis). The current assessment indicated that the area of land allocated for improved forage production among the respondent farmers was reported to vary from 0.01 to 3 ha with annual forage production potential of 270-36,000 kg per annum. 
Lemu Bilbilo and Tiyo districts of Arsi Zone - Feed supply is inadequate in the area. But there are increasing trends of improved forage production, especially Desho grass and oats. In addition to the SNV EDGET project, Kulumsa Agricultural Research Centre is also demonstrating improved forage production in the area.

Degem district, North Shewa Zone - There is high demand for feed but the supply is not adequate. Improved forages such oats, vetch, and Desho grass are doing very well.

Shashemene district, West Arsi Zone, Oromia - There is scarcity of feed supply and high cost of feed in the district. The cost of concentrate feeds is particularly high because of transport cost. There is no experience in forage seed production and there is no supplier of certified seed. Thus, more attention needs to be given to the development livestock feed subsector in the area.

Tigray

Enderta, Hintalo-Wajirat, Kilte-Awlealo and Hawzen districts of Tigray region - These districts are affected by inadequate supply of feed and shortage of forage seeds. Because of shortage, the price of forage seeds is very high. For example, $1 \mathrm{~kg}$ of alfalfa seed is occasionally sold for 1,100.00 Birr. It was reported that there is no recognized forage seed supplier in the region and there is no system for forage seed quality control.

It was reported that the attention given to feed and forage development is not adequate because of crop dominated extension system and high turnover rate of extension staff. In general, equal emphasis is not being given to forage and feed development as compared to other agricultural extension activities. As a result the awareness of farmers is low and also the linkage between research and extension is poor. Forage extension in the region focuses on limited number of forage crops such as elephant grass and alfalfa. There is training gap for the extension staff and the extension service is biased towards crops and natural resources. The extension staffs (development agents) are over burdened by providing administrative support services thereby reducing their time, credibility and effectiveness in extension delivery.

\subsection{Experience of the farmers in forage production}

The adoption, production and utilization of improved forage crops as sources of animals feed was reported to be low in all of the areas assessed. The farmers reported variable degree of prior experience in forage crop production. Most farmers reported lack of prior experience or exposure to improved forage production. This was unexpected considering nearly five decades of research and development efforts on improved forage production and utilization. Although the farmers are facing critical shortage of feed supply, efforts to produce improved forage crops is generally very low unless there is a project support. When the farmers get project support they become very keen and show good performance in improved forage production. However, the main challenge is sustaining that level of performance when the project phases out.

A number of interrelated factors were mentioned as forage production challenges and causal factors for low adoption rate of improved forage production. These include:

- Shortage of land and competition for land with crop production. This challenge was cited by $47 \%$ of the respondents from Tigray region. There is a general notion of prioritizing cereal and vegetable production over forage crops and tendency of allocating only marginal areas for forage production.

- Lack of proper awareness and knowhow in forage production, management and utilization.

- Free grazing of animals discourages farmers to invest in production of improved perennial forage crops if the established forages are to be destroyed by free roaming animals.

- Seasonal rainfall distribution and scarcity of water was another challenge hindering production of improved forage crops. In all parts of the country, there is marked seasonality in rainfall distribution and nowadays there is a general trend of having a prolonged dry season. Scarcity of water that can be used to irrigate the planted forages during the long dry season limits the options available to produce improved forages. 
- Unavailability of forage seeds. The supply of improved forage seeds is limited to some NGOs and government institutions. The types and amount of forage seeds produced and marketed in the country is very much limited. In addition, there is no regulation and quality control system of the forage seeds marketed in the country.

- Low technical support to the farmers. Although development agents (DAs) are assigned to each rural kebele, the farmers indicated that they are not getting adequate technical support in this regard. This could be related to technical limitations of the DAs themselves or the DAs might pay less attention to forage extension and give more priorities to other activities.

When asked how to alleviate the feed shortage problem, the interviewed farmers and the key informants suggested the following as possible measures.

- Giving more attention to improved forage production. For this proposition to be acceptable and successful due attention should be given to those species adapted to the given agro-ecology and production system as well as to species that have high yield potential and high nutritional value.

- Training of farmers on improved forage production and utilization. The farmers need to properly understand the benefits of improved forages, the cost of production and should have the necessary technical knowhow for proper establishment, management and utilization of the improved forages. The extension system should demonstrate good management practices and more effective ways of utilizing the established forage crops to enhance livestock productivity and economic wellbeing of the farm households.

- Pond construction to alleviate the water shortage problem to irrigate the established forage crops.

- Control free grazing of animals. Free roaming animals can destroy perennial forage crops. This discourages farmers from investing on forage production. Therefore, free roaming animals need to controlled i.e. the farmers should practice controlled grazing with the help of a herder or by tethering the animals and in very densely populated and intensively cropped areas it might be worthwhile to adopt zero grazing system.

- Improving utilization of crop residues and agro-industrial by-products. Crop residues represent the widely available feed biomass in all the assessed sites. Thus, proper management and utilization of this huge feed resource base is very vital to realize the benefits of improved forage crops, which are mostly produced in relatively small quantities and can only serve as supplementary feed to crop residues and natural pastures based diets. In addition, agro-industrial by-products can be used as complementary feeds to improved forages in areas where the agro-industrial by-products are easily accessible with reasonable cost.

The experience of farmers in forage production varies from region to region and from zone to zone or from district to district within a region.

\subsubsection{Tigray region}

Most of the interviewed farmers indicated that they have some prior experience in forage production. Farmers that have crossbred dairy cows produce more improved forages. The most common forage crops grown include alfalfa, elephant grass, Leucaena and Sesbania, pigeon pea, Siratro, Phalaris, Rhodes grass, buffel grass, Desho grass, vetch and cow pea in different agro-ecologies of the region (Figure 1).

Farmers who keep crossbred cows and reside near the main roads produce more forage and also buy other supplementary feeds for their animals. The area of land allocated for improved forages was reported to vary from as low as 0.0025 ha $(25 \mathrm{~m} 2)$ to as high 10 ha (exceptional one farm) with an average of $953 \pm 1610 \mathrm{~m} 2$. The annual forage production varied from 50 to $7800 \mathrm{~kg}$. Farmers who are far away from market produce less forage and give less attention to its management. About $86 \%$ of the farmers reported that the amount forage they produce is very small and not sufficient to feed their animals. Out of 13 farmers who reported about buying and selling of forage, 12 farmers (92.3\%) indicated that they buy additional feeds and forages whereas one of the 13 farmers indicated selling when he has excess and buying when faced with shortage of feed. 


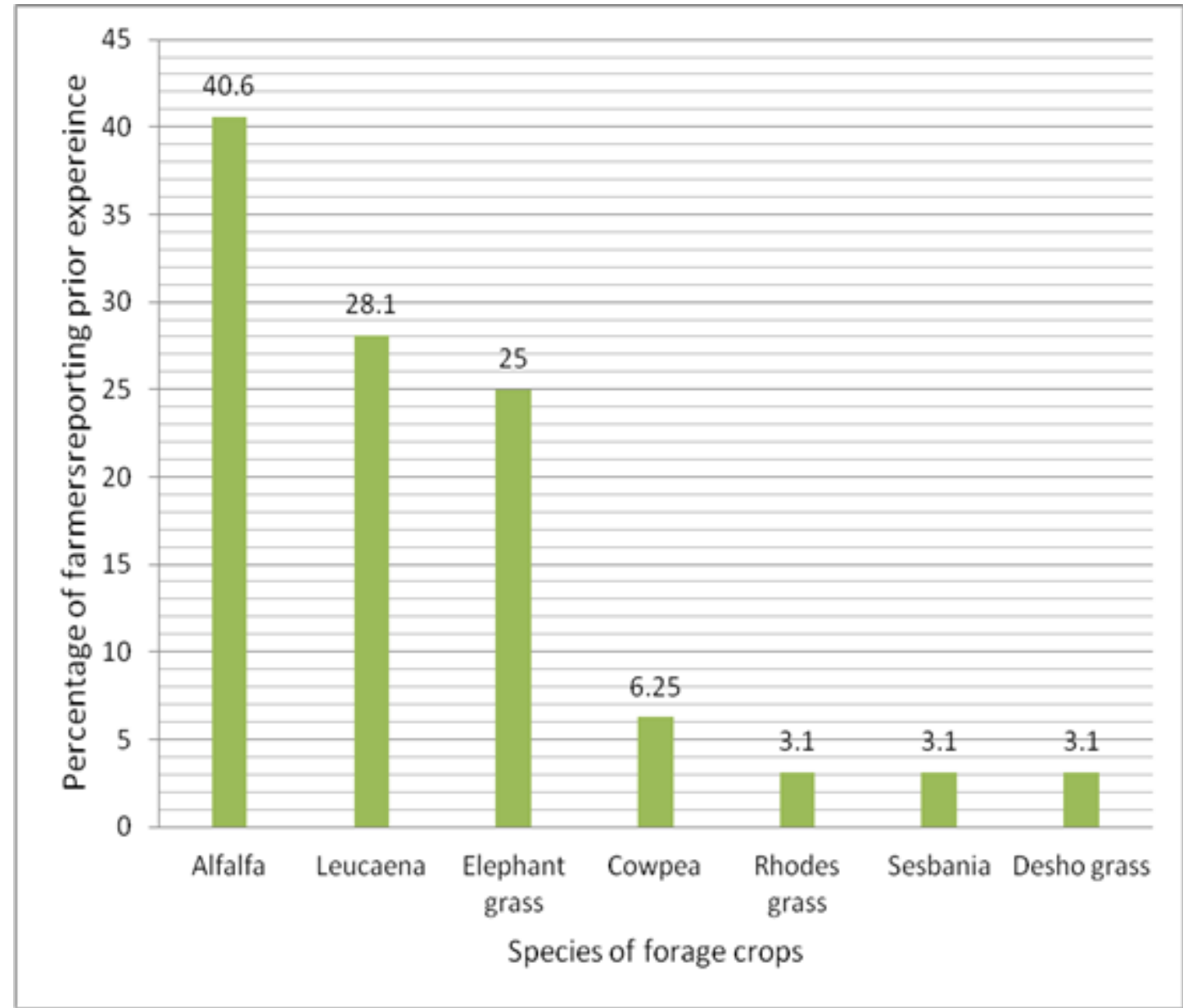

Figure 1 Percentage of farmers reporting prior experience in the production of certain types of forage crops in the four districts of South Eastern and Southern Zones of Tigray Regional State.

\subsubsection{SNNPR}

Sidama zone: About $44 \%$ of the interviewed farmers from Dale district and Shebedino districts reported having prior experience in cultivated forage production whereas the remaining $56 \%$ indicated that they did not have prior experience. In both districts, the farmers were mainly growing cuttings of Desho and elephant grass and were not involved in the production other forage crops.

\subsubsection{Amhara Region}

Dangila district, Awi Zone: About $87.5 \%$ of the respondents indicated that they did not have prior experience in improved forage production. This percentage appears to be too high considering many years (over five decades) of forage research and development efforts made in the country. Some farmers reported having experience of producing Rhodes grass, Desmodium and Sesbania.

Awabel district, East Gojjam zone: Some farmers expressed prior experience in cultivated forage production. The existing forage crops include elephant grass, sesbania, vetch and oats.

Fogera district, South Gondar zone: Some farmers expressed prior experience in cultivated forage production. Elephant grass, sesbania and pigeon pea were some of the improved forages previously introduced into the area. Because of shortage of feed, some farmers buy additional feed from outside. 


\subsubsection{Oromia}

Arsi zone: The farmers in the area have prior experience in improved forage production, which is believed to be the legacy of the work of Arsi Rural Development Unit (ARDU) and the research and extension activities that followed afterwards by Kulumsa Agricultural Research Center and by the zonal Department of Agriculture and Livestock Resources. The existing forage crops in the area include alfalfa, fodder beet and tree lucerne.

North Shewa zone (Selale): The farmers in Selale area also have prior experience in improved forage production, which is believed to be influenced by previous research and development projects such the Selale Dairy Development Project funded by the Finland government, Smallholder Dairy Development Project etc. The main forage crops widely grown in the area include oats, vetch and tree lucerne.

West Arsi zone, Shashemene district: Existing forage crops grown by some farmers in the district include elephant grass, Desho and sesbania.

East Shewa zone, Ada'a district: The existing forage crop crops grown by some farmers in the district include oats, vetch, elephant grass, alfalfa and sesbania.

\section{Area of land allocated for forage production}

The area of land allocated for forage production varies from region to region and from district to district within region based on land availability and production environment. The smallest area of land allocated was $20 \mathrm{~m} 2(5 \mathrm{~m} \mathrm{X} 4 \mathrm{~m}$ ) and this was reported in Tigray region. In most cases, the area of land allocated for forage production in Tigray region varies from $100 \mathrm{~m} 2(10 \mathrm{~m} \times 10 \mathrm{~m})$ to 0.25 ha with few exceptions. The higher end of forage land is allocated by farmers who keep crossbred cows that produce greater than 10 litres of milk per cow per day. These are very few farmers located north of Mekelle town. These farmers produce forages extensively similar to other crops. The forage yield could be as high as 30 quintals of fresh forage with about $70 \%$ moisture content.

In Dangila district of Awi zone, Amhara Regional State, the area of land allocated for forage production varies from $100 \mathrm{~m} 2$ to 0.5 ha of Rhodes grass and it was reported that the farmers produce about 1.5 -20 quintals of green forage a year.

The forage producers in Dale and Shebedino districts of Sidama zone indicated that they allocated about 0.125 to 1.0 ha of land for cultivated forage production and produce as high as 40 quintals of fresh forage with a minimum of 4-5 quintals. It was reported that one farmer sold Mulato II cuttings for 36,000.00 Birr.

Because of diversity of agro-ecology, production system and land availability, the area of land allocated for forage production in different zones and districts of Oromia Regional State are very variable. The area of land allocated for forage production in Arsi zone of Oromia region varies from $500 \mathrm{~m} 2$ to 0.75 ha including oats and vetch and some perennial forage crops. The maximum area of land allocated for perennial forage crops does not exceed 0.25 ha. An exceptional farmer who has many dairy cows allocates around 3 ha of land for production of Rhodes grass, Desho, elephant grass and oats and vetch with annual production of 70 quintals of green forage and 1-2 quintals of forage seed (oats and vetch seed). In Ada'a district, the area of land allocated for oats and vetch production ranges from $200 \mathrm{~m} 2$ to 1 ha whereas for other forage crops it varies from $50 \mathrm{~m} 2$ to $200 \mathrm{~m} 2$. The area of land allocated for production of oats and vetch in North Shewa zone (Selale) varies from 0.25 to 2.0 ha with an average of 0.75 ha per household. In addition, perennial forages such as Desho and tree Lucerne are grown on less than 0.125 ha of land. 


\subsection{Introduction and distribution of fodder seeds and planting materials}

\subsubsection{Actors involved in supply of forage seed and/or planting materials}

All the respondents of this study were recipients of forage seeds and/or planting materials distributed by either SNV EDGET Project (Oromia, Amhara and SNNP Regions) or Mekelle University and Tigray Bureau of Agriculture and Natural Resources (Tigray Region). In addition, some development partners and government agencies have supplied forage seeds or planting materials to some farmers in the study areas at one point in time. These include Agricultural Cooperative Development International/Volunteers in Overseas Cooperative Assistance (ACDI/VOCA) and German International Cooperation (GIZ) for the Sustainable Land Management (SLM) Project in all regions, Ethio-Nile and Eshet Plc in Amhara region, Relief Society of Tigray (REST) in Tigray region, Oromo Self Reliance Association (OSRA) and Bishoftu Research Center in Ada'a district, Sidama Zone Livestock Department in Dale district and Family Milk in Degem district. The list of different species forage seeds or planting materials distributed to farmers in the four regions by SNV Edget project (in the selected districts of Amhara, Oromia and SNNP regional States) and by Mekelle University and the Tigray Region Bureau of Agriculture and Natural Resources is summarized in Table 6.

Table 6 Types forage seeds and planting materials distributed to the different districts and kebeles

\begin{tabular}{|c|c|c|c|}
\hline Region & Zone & District & Forage crops distributed \\
\hline Amhara & Awi & Dangila & $\begin{array}{ll}\text { - } & \text { Desho } \\
\text { - } & \text { Rhodes grass } \\
\text { - } & \text { Elephant grass } \\
\text { - } & \text { Oats-vetch } \\
\text { - } & \text { Alfalfa }\end{array}$ \\
\hline Oromia & Arsi & $\begin{array}{l}\text { Bokoji } \\
\& \\
\text { Tiyo }\end{array}$ & $\begin{array}{ll}\text { - } & \text { Desho } \\
\text { - } & \text { Elephant grass } \\
\text { - } & \text { Oats-vetch } \\
\text { - } & \text { Alfalfa } \\
\text { - } & \text { Fodder beet } \\
\text { - } & \text { Rhodes grass (Tiyyo only) }\end{array}$ \\
\hline
\end{tabular}




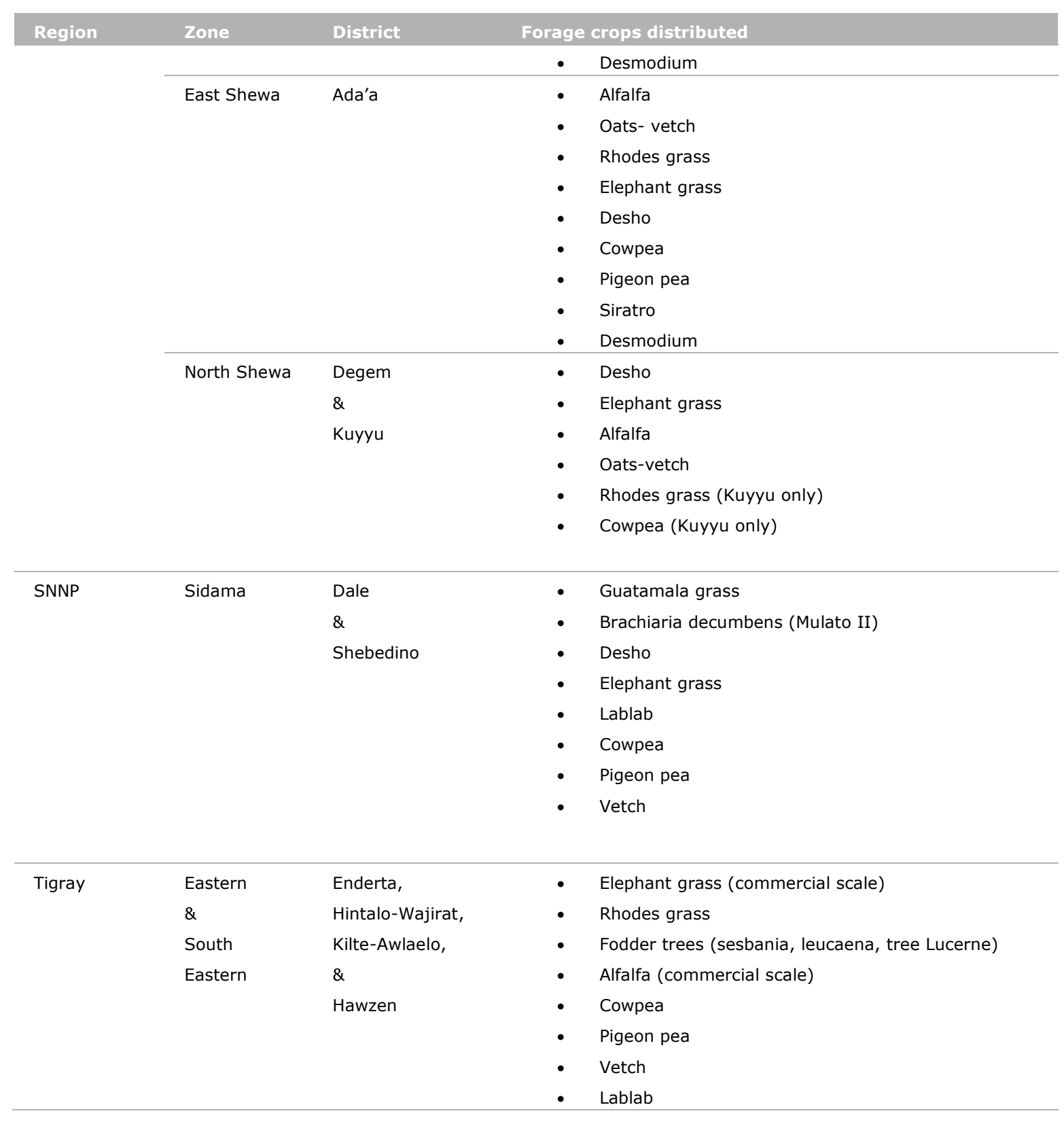

\subsubsection{Preconditions set to qualify for receiving the forage seeds and/or planting materials}

Both the SNV EDGET project and the Mekelle University \& Tigray Bureau of Agriculture and Natural Resources team have set certain criteria to be fulfilled by the farmers in order to qualify to receive the seeds and/or planting materials. These include:

SNV EDGET Project

- Availability of land for forage development. The seed/planting material recipient farmers should have at least $100 \mathrm{~m} 2$ of land for backyard forage production.

- Ownership of at least one crossbred cow or heifer or a local cow with good milk production performance. In the case of female headed households ownership of one good performing local cow would be acceptable.

- Willingness to develop forages i.e. willingness to multiply the improved forages and demonstrate to other farmers

- Participation in the training given by project implementers

Mekelle University/Tigray Bureau of Agriculture and Natural Resources

- Ownership of Holstein Friesian crossbred cow/heifer

- Availability of irrigation facility 
- Reception of extension advice

- Previous experience in forage development

- Availability of a minimum of $200 \mathrm{~m} 2(10 \mathrm{~m} \mathrm{X} 20 \mathrm{~m}$ ) of land for forage production

- Interest and willingness to develop forages

\subsubsection{The type and amount forage seed or planting material distributed}

There are differences and similarities in the type types or species of forage seeds and planting materials distributed to different regions, zones, districts and kebeles depending on agro-ecology of the area and adaption range of the forage crops. Some forage crops have wide range of adaptation to different agro-ecologies and production systems whereas some species have specific agro-ecological niches. For instance, the forage crops commonly grown in Degem district of North Shewa Zone, Oromia Regional State, include oats, vetch, desho grass, elephant grass and tree lucerne. Similarly, the forage crops grown in Tiyo district include Desho grass, oats and vetch, fodder beet, Sesbania, Elephant grass and alfalfa in decreasing order of importance.

Decision on selection of the forage seeds and planting materials was made jointly by the farmers and the experts or extension advisors. The main criteria considered in this respect include availability of land for the type of forage considered, biomass yield potential of the forage species and availability of seed (type of seed available).

The amounts of forage seeds and/or planting materials distributed to the different farmers varies from farmer to farmer depending upon availability of land, the number of animals owned as well as the enthusiasm of the farmer. Tables 7, 8, 9, 10, 11 and 12 show the types and amount of forage seeds and planting materials (cutting or splits) distributed to the interviewed farmers in some of the districts selected for the assessment from the four regional states.

Table 7 The types and amount of forage seeds and planting materials distributed in Eastern and South Eastern zones of Tigray Regional State.

\begin{tabular}{llll} 
Forage species & Year I & Year II & Year III \\
Alfalfa & $0.25-25 \mathrm{~kg} *$ & $0.25-3.5 \mathrm{~kg}$ & $0.03-15 \mathrm{~kg}$ \\
\hline Cow pea & $1 \mathrm{~kg}$ & $0.5-5 \mathrm{~kg}$ & $2-3 \mathrm{~kg}$ \\
\hline Vetch & & $3.5 \mathrm{~kg}$ & $0.5 \mathrm{~kg}$ \\
\hline Rhodes grass & & $2.5 \mathrm{~kg}$ & $2.5 \mathrm{~kg}$ \\
\hline Leucaena & $10-250$ seedlings & $10-600$ seedlings & $10-1000$ seedlings \\
\hline Elephant grass & $40-200$ cuttings & $13-2500$ cuttings & $24-700$ cuttings \\
\hline Desho grass & & $52-3000$ cuttings & 20 cuttings \\
\hline
\end{tabular}

*Most farmers received $1-2 \mathrm{~kg}$

Table 8 The types and amount of forage seeds and planting materials distributed in Fogera district of Amhara Regional State.

\begin{tabular}{llll} 
Forage species & Year I & Year II & Year IIII \\
Oats & $10-15 \mathrm{~kg}$ & $10-25 \mathrm{~kg}$ & $10-15 \mathrm{~kg}$ \\
\hline Cow pea & $15 \mathrm{~kg}$ & $15-20 \mathrm{~kg}$ & $10 \mathrm{~kg}$ \\
\hline Vetch & & $10-25 \mathrm{~kg}$ & $10 \mathrm{~kg}$ \\
\hline Rhodes grass & & $6 \mathrm{~kg}$ & $2000-3000$ cuttings \\
\hline Sesbania & $2500-4000$ cuttings & $10-64-6 \mathrm{~kg}$ & $1000-2000$ cuttings \\
\hline Elephant grass & & 2000 cuttings \\
\hline Desho grass & & 2000 cuttings & \\
\hline
\end{tabular}


Table 9 The types and amount of forage seeds and planting materials distributed in Dale and Shebedino districts of Sidama Zone, SNNPR.

\begin{tabular}{llll} 
Forage species & Year I & Year II & Year IIII \\
\hline Lablab & $0.5-2 \mathrm{~kg}$ & $0.5-1 \mathrm{~kg}$ & $10-15 \mathrm{~kg}$ \\
\hline Cow pea & $0.5-1 \mathrm{~kg}$ & $0.5-1 \mathrm{~kg}$ & $10 \mathrm{~kg}$ \\
\hline Vetch & $0.5-1 \mathrm{~kg}$ & $0.5 \mathrm{~kg}$ & $10 \mathrm{~kg}$ \\
\hline Pigeon pea & $0.5-1.5 \mathrm{~kg}$ & $0.5 \mathrm{~kg}$ & $200-1500$ cuttings \\
\hline Rhodes grass & $0.5-1 \mathrm{~kg}$ & $0.5-1 \mathrm{~kg}$ & $250-500$ cuttings \\
\hline Desho grass & $200-1000$ cuttings & $200-2000$ cuttings & 250 cuttings \\
\hline Elephant grass & $150-600$ cuttings & $150-800$ cuttings & $120-1000$ cuttings \\
\hline Guatamala grass & $120-300$ cuttings & 1500 cuttings
\end{tabular}

Table 10 The types and amount of forage seeds and planting materials distributed in Shashemene district of West Arsi Zone, Oromia Regional State.

\begin{tabular}{lll} 
Forage species & Year I & Year II I \\
\hline Oats & $3-40 \mathrm{~kg}^{\mathrm{a}}$ & $4-40 \mathrm{~kg}^{\mathrm{e}}$ \\
\hline Vetch & $1-10 \mathrm{~kg}$ & $2-10 \mathrm{~kg}$ \\
\hline Alfalfa & $0.5-15 \mathrm{~kg}^{\mathrm{b}}$ & $0.5-10 \mathrm{~kg}$ \\
\hline Cow pea & $2-15 \mathrm{~kg}^{\mathrm{c}}$ & $3-10 \mathrm{~kg}$ \\
\hline Pigeon pea & $1-12 \mathrm{~kg}^{\mathrm{d}}$ & $1-2 \mathrm{~kg}$ \\
\hline Rhodes grass & $2-8 \mathrm{~kg}$ & $2-10 \mathrm{~kg}$ \\
\hline Desho grass & $200-2000$ cuttings & $20-1000$ cuttings
\end{tabular}

a Most farmers received 3-6 kg bMost farmers received 0.5-1 kg cMost farmers received 2-4 $\mathrm{kg}$ dMost farmers received 1-4 kg

eMost farmers received $4-6 \mathrm{~kg}$

Table 11 The types and amount of forage seeds and planting materials distributed in Tiyo district of Arsi Zone, Oromia Regional State.

\begin{tabular}{llll} 
Forage species & Year I & Year II & Year IIII \\
Oats & $3-20 \mathrm{~kg}$ & $3-30 \mathrm{~kg}$ & $5-20 \mathrm{~kg}$ \\
\hline Vetch & $2-10 \mathrm{~kg}$ & $3-15 \mathrm{~kg}$ \\
\hline Alfalfa & $0.5-1 \mathrm{~kg}$ & \\
\hline Desho grass & $200-1500$ cuttings & $200-1000$ cuttings \\
\hline Elephant grass & $500-700$ cuttings & $50-1000$ cuttings
\end{tabular}


Table 12 Forage seed and planting materials distributed to farmers in Degem district, North Shewa zone, Oromia

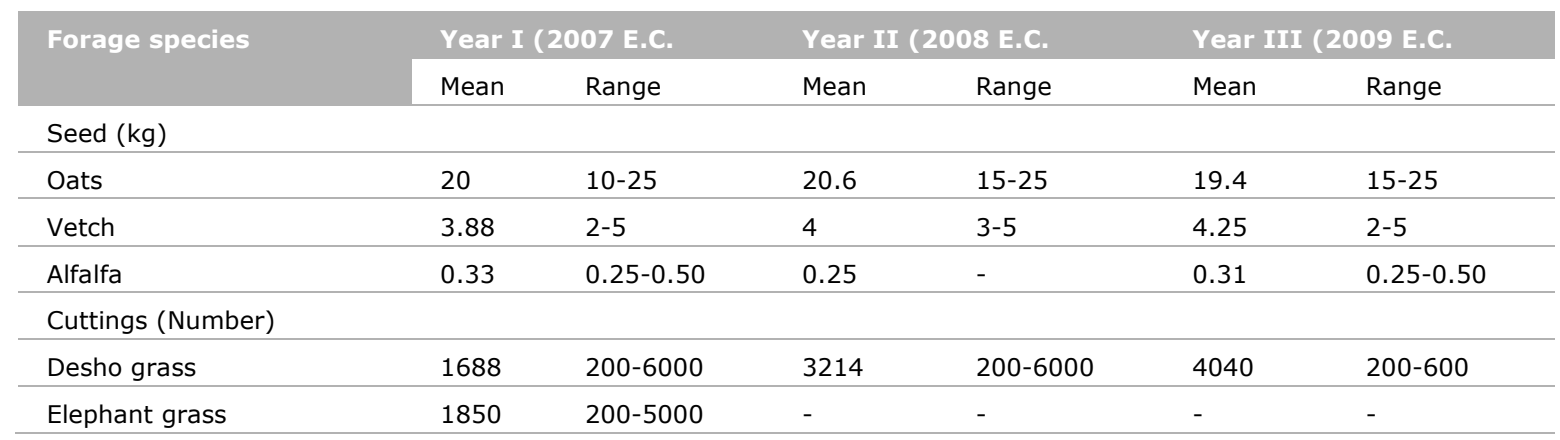

In Dale and Shebedino districts of Sidama Zone, SNNPR, forage crops propagated by cuttings and splitting are more popular because of ease of establishment and management. Thus, Desho, Elephant grass and Gutamala grass are the most widely grown grasses by the respondents. All the respondents grow Desho and Elephant grass (Figure 2). Among the legumes, lablab is the most widely grown forage followed by cowpea and pigeon pea. The seed production and establishment of these legumes is relatively easy compared to other forage crops propagated by seed.

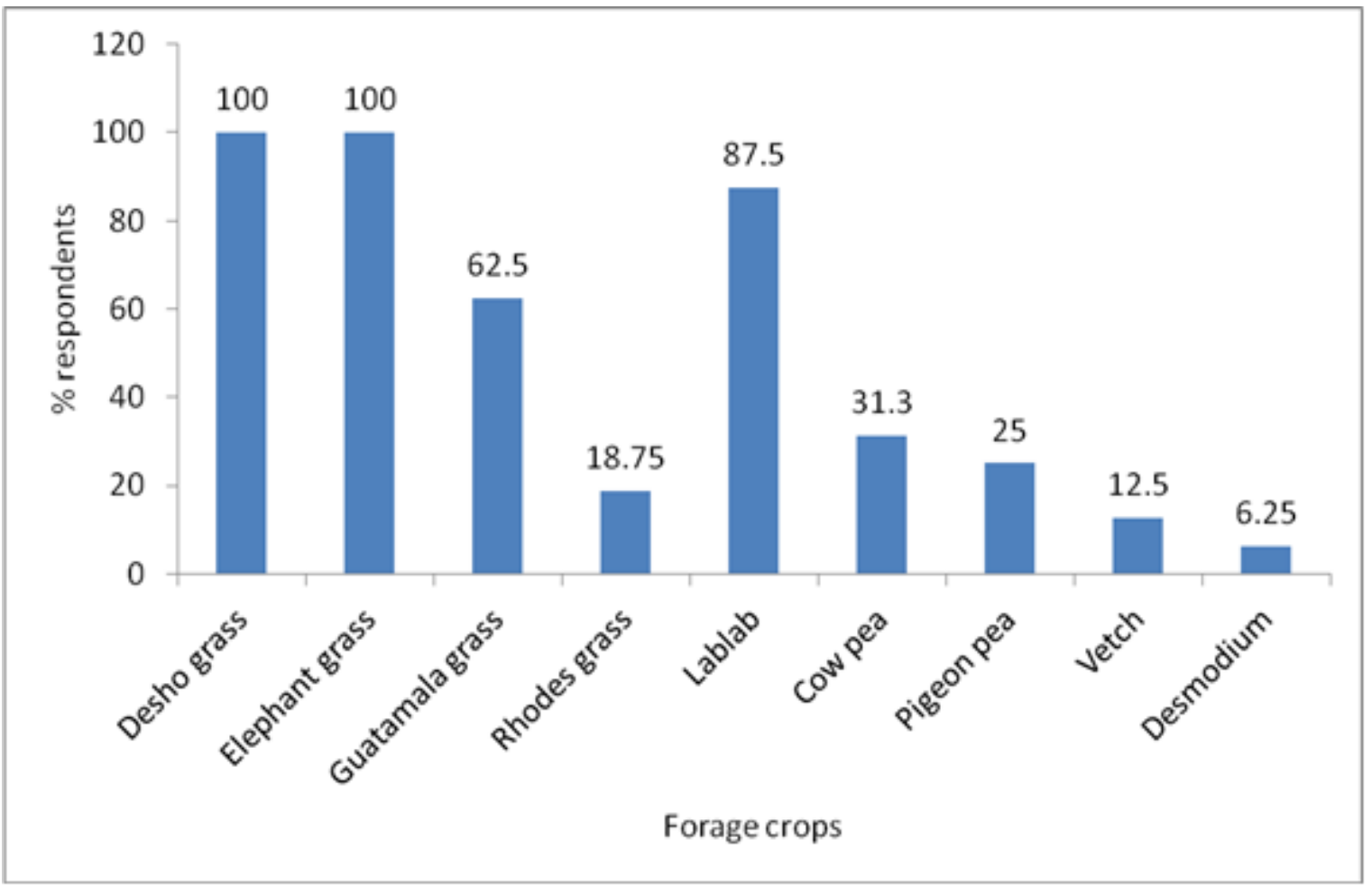

Figure 2 Percentage of farmers reporting production of different forage crops in Dale and Shebedino district of Sidama Zone, SNNPR.

\subsubsection{Area of land planted to improved forage crops}

The area of land planted to different improved forage crops varies depending upon type or species of forage, availability of land on each farm as well as the interest and commitment of the farmer. Some of the forage crops require wider area of land to produce sufficient biomass that can be fed to animals while some other forage crops can produce high amount of biomass on small plot of land. For example, the average area of land allocated for forage production in Tiyo district was reported to be 0.297 \pm 0.163 ha with a range of 0.125-0.5 ha. Similarly, the area of land allocated for forage production in Ada'a district of East Shewa zone, Oromia, is $0.083 \pm 0.074$ ha with a range of 0.015 to 
0.20 ha. Tables 13, 14 and 15 and Figure 3 show the area of land planted to the different forage crops distributed to the interviewed farmers in selected districts in the four regional states.

Table 13 The area of land planted to improved forages in Eastern and South Eastern zones of Tigray Regional State.

\begin{tabular}{|c|c|c|c|}
\hline Forage species & Year I & Year II & Year III \\
\hline Alfalfa & $50 m^{2}-1$ ha & $30 m^{2}-2$ ha & $30 m^{2}-3 h a$ \\
\hline Cow pea & $150 \mathrm{~m}^{2}$ & $400 \mathrm{~m}^{2}$ & \\
\hline Vetch & 1 ha & 2 ha & 3 ha* \\
\hline Rhodes grass & 0.004-0.006ha & $200 \mathrm{~m}^{2}-0.07 \mathrm{ha}$ & \\
\hline Leucaena & $0.02 \mathrm{ha}$ & $50 m^{2}-200 m^{2}$ & \\
\hline Elephant grass & & $50 \mathrm{~m}^{2}$ & \\
\hline Desho grass & & $100 \mathrm{~m}^{2}-0.08 \mathrm{ha}$ & \\
\hline
\end{tabular}

*only 1 farmer

Table 14 The area of land planted to improved forages in Dale and Shebedino districts of Sidama Zone, SNNPR.

\begin{tabular}{|c|c|c|c|}
\hline Forage species & Year I & Year II & Year III \\
\hline Lablab & $0.04-0.125$ ha & $0.05-0.125$ ha & $0.025-0.125$ ha \\
\hline Cow pea & $0.024-1.0$ ha & $0.025-0.05$ ha & $0.025-0.06$ ha \\
\hline Vetch & $0.04-0.11$ ha & $0.05-0.08$ ha & 0.05 ha \\
\hline Rhodes grass & $0.08-0.128$ ha & $0.005-0.128$ ha & 0.025 ha \\
\hline Desho grass & $0.015-0.25$ ha & $0.02-0.25$ ha & $0.02-0.215$ ha \\
\hline Mulato II & & & 0.12 ha \\
\hline
\end{tabular}

Table 15 The area of land planted to improved forages in Shashemene district of West Arsi Zone, Oromia Regional State.

\begin{tabular}{lll} 
Forage species & Year II & Year II \\
Oats & $0.02-0.5 \mathrm{ha}$ & $0.02-0.0625$ \\
\hline Vetch & $0.01 \mathrm{ha}$ & $0.01-0.5 \mathrm{ha}$ \\
\hline Alfalfa & $0.02-0.5 \mathrm{ha}$ & $0.01-0.02 \mathrm{ha}$ \\
\hline Cow pea & $0.01-0.25$ ha & $0.01-0.25$ ha \\
\hline Pigeon pea & $0.02-0.2 \mathrm{ha}$ & $0.01 \mathrm{ha}$ \\
\hline Rhodes grass & & $0.001-0.25 \mathrm{ha}$
\end{tabular}




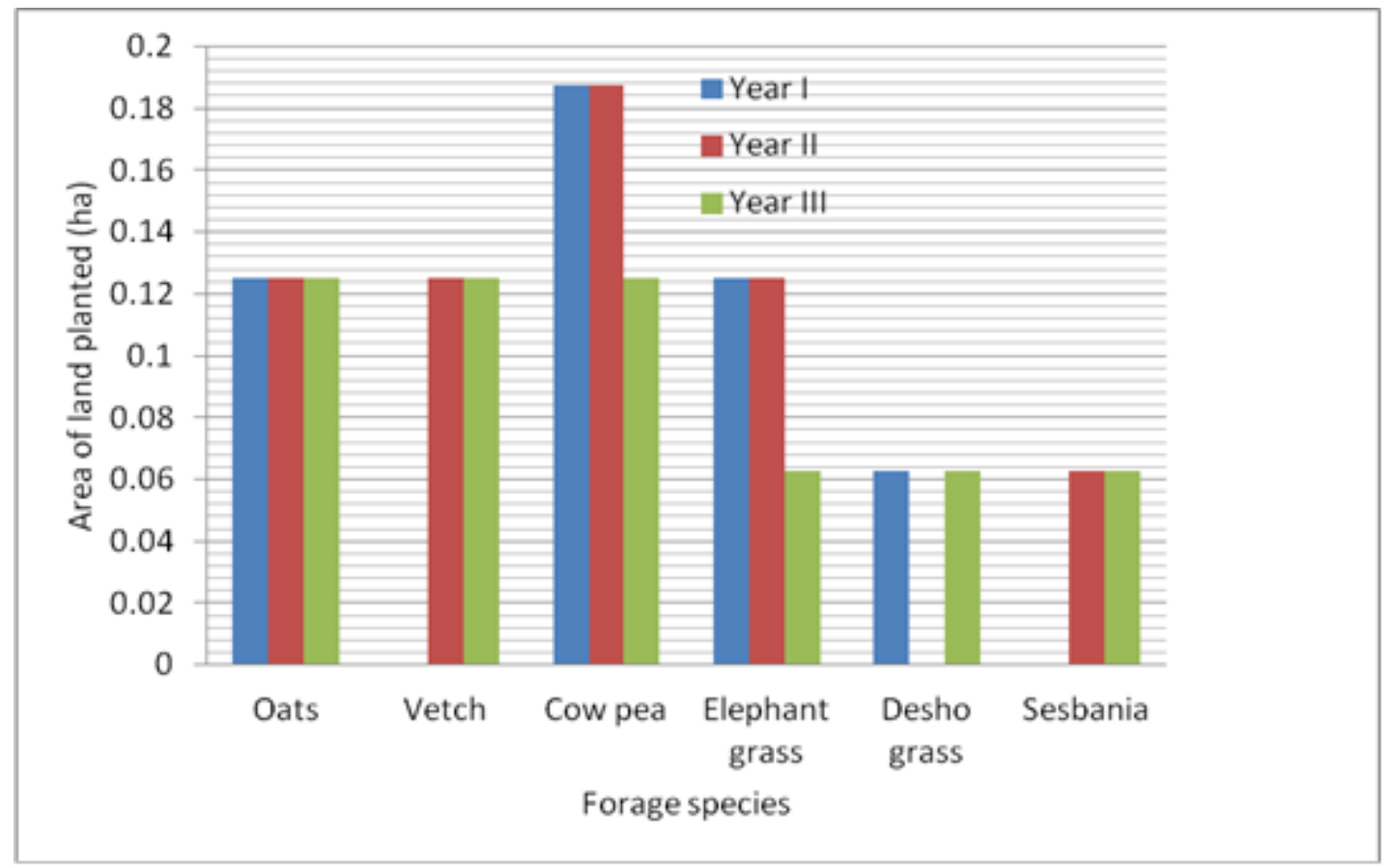

Figure 3 The area of land planted to improved forages in Fogera district of Amhara Regional State.

In Degem district, the area of land allocated for forage crop production was reported to be around $1.09 \pm 0.56$ ha with a range of $0.43-2.0$ ha (Table 16 ). The area of land under improved forage crops is increasing in the district because of increasing number of crossbred dairy animals kept by the farmers and decreasing availability of grazing land and alternative feed resources. The annual production of fresh forage is estimated to be $5760 \mathrm{~kg}$ with a range of $585-14,400 \mathrm{~kg}$. The forage produced is not sufficient for the number of animals kept by the farmers. This is due to shortage of land for grazing and for forage production. In addition, forage production is seasonal due to lack of irrigation facilities and irrigable land. Shortage of forage seed supply is another bottleneck hampering production of improved forages. Moreover, the number of animals kept by each household is more than what the available feed resources can support.

Table 16 Area of land allocated for improved forage production in Degem district.

\begin{tabular}{ll} 
Forage species & Area of land allocated \\
Oats & $0.25-1$ ha \\
\hline Oats+Vetch & $0.18-2$ ha \\
\hline Desho & $200 \mathrm{~m}^{2}-0.25$ ha \\
\hline Tree lucerne & 200 plants \\
\hline
\end{tabular}

Shortage of land and competition for land between forage and crop production, shortage of forage seeds and planting materials and shortage of water for irrigation and the weather condition such shortage rain or occasional frost are among the challenges affecting forage production in the area.

\subsubsection{Criteria for selection of the species of forage crops grown}

The type or species of forage crops distributed to the farmers in different locations were mainly decided by the project staff and district and kebele level development workers. Agro-ecology, soil type and other environmental conditions as well as adaptability of the candidate forage crops to the agroecology are the main considerations for the selection of a particular forage species for distribution to farmers in the different zones and districts. Although not explicitly declared in the assessment, the 
types or species of forage seeds and/or planting materials available should also be one of the determinants. This is because of limited sources of forage seeds and planting materials.

It seemed that the farmers had very little say in the selection of the species of forage crops they were given. Ideally, the farmers should have more say in the selection of the type of forage crop he/she is going to produce, of course based on proper advice. The best way would be to give a basket of different forage species or variety options to the farmers so that they select those species or varieties they are more interested in. For example, the farmers in Dale and Shebedino districts of Sidama zone, SNNPR, were not interested in forage crops propagated by seeds such as Rhodes grass and alfalfa. Their preference was for species that can easily be propagated by cuttings or splitting such Desho and Elephant grass. Thus, the farmers in the two districts reported that they were not happy with the initial decision of the project staff and the development agents and negotiated for their interests to be taken into account in the selection of the types of forage species distributed to them.

\subsubsection{Preparations made before distribution and establishment of the forage crops}

After preparation of the project documents, the partners identified the zones and districts that serve as project sites. This was followed by selection of participating farmers depending on already set criteria such as availability of land, availability of crossbred or high producing local cows as well as interest or willingness of the farmers to engage in forage and forage seed/planting material production for own use and for sale as income generating activity.

The selected farmers were given about 2-3 days of training and awareness creation activities on forage and forage seed production techniques and practices. It was reported that trainings were given twice a year for a period of 2-3 days by the project staff, district experts and development agents.

\subsubsection{Current area of planted forage owned by the farmers}

The information obtained from the interview on the area of land currently covered by planted forages is not conclusive. However, there are indications that some farmers have maintained the same area of land planted to forage during the three project years whereas some farmers have lost part or all of the established forages. Some farmers lost the established forages due to damage by free roaming animals, prolonged dry season and lack of water for irrigation, hailstorm and lack of proper appreciation of the value of the improved forages. But there are also some encouraging reports that a few farmers have actually expanded the area of land planted to forage crops. Table 17 shows the current area of land planted to forage in Tigray and in Fogera district of South Gondar Zone, Amhara Regional State.

In Degem district of Oromia Region, an increasing trend of area of land under improved forage crops has been reported because of increasing number of crossbred dairy animals kept by the farmers and decreasing availability of grazing land and shortage of alternative feed resources. The current area of land under improved forage crops in Dale and Shebedino districts vary from 0.015 to 1.75 ha with an average and standard deviation of 0.38 and 0.52 ha, respectively. The high value of standard deviation compared to the mean indicates the high degree of variability among individual farms on the area of land allocated for improved forage production.

Table 17 Current area of land covered by planted forages in Eastern and South Eastern zones of Tigray Region and in Fogera district of Amhara Region.

\begin{tabular}{lll} 
Forage species & Tigray Region & Fogera district \\
Alfalfa & $60 \mathrm{~m}^{2}-2$ ha & $0.0625-0.125$ ha \\
\hline Cow pea & $150 \mathrm{~m}^{2}$ & \\
\hline Vetch & $30-200 \mathrm{~m}^{2}$ & 0.125 ha \\
\hline Rhodes grass & & \\
\hline Leucaena & $30-200 \mathrm{~m}^{2}$ & $0.0625-0.125 \mathrm{ha}$ \\
\hline Elephant grass & $100 \mathrm{~m}^{2}-0.07 \mathrm{ha}$ & \\
\hline Sesbania & $50 \mathrm{~m}^{2}$ &
\end{tabular}




\subsection{Adequacy of the amount of forage produced}

Nearly all the interviewed farmers indicated that the amount of forage produced is not sufficient for their animals and most of them buy additional feed from other sources. Most farmers buy agroindustrial by-products (wheat bran, oilseed cakes and atela) mostly during the dry season. All respondents from Oromia indicated that the amount of forage produced on their farm is not sufficient for their animals. Only one farmer who owned very few animals said that the amount of forage he produced was sufficient for his animals. The following reasons were cited as possible causes for not producing enough forage.

- Shortage of land and land competition with other crops

- Lack of forage seeds and planting materials. There is no established forage seed and planting supply system and it is not possible to get certified seeds.

- High cost of forage seeds/planting materials

- Lack of knowhow (training)

- Shortage of labour

- Keeping more number of animals than the available feed resources can support.

When the amount of forage produced is limited farmers prioritize some of the animals over the others. Milking cows and calves often have the first priority followed by pregnant cows and heifers. However, during ploughing period, draught oxen have high priority next of lactating cows and sometimes they get higher priority even than lactating cows.

The following measures were suggested as possible solutions to alleviate the problem of livestock feed shortage.

- Allocating some crop land for improved forage production. So far the general trend has been to allocate all productive lands for crop production and push forage production to marginal land that is not suitable for any crop production without any cost-benefit analyses. However, for peri-urban mixed crop-livestock dairy farmers, improved forage production could be more cost effective than cereal crop production. Thus, land allocation should be based on proper evaluation of the opportunity cost of using the land either for crop or for forage production.

- Renting land for forage production from those farmers who have large land holdings.

- Producing own forage seed

- Buying and feeding concentrates as supplementary feeds

- Improving crop residues to enhance their nutritive value and utilization

- Reducing the number of livestock and keeping only more productive animals

- Conserving forage as hay or silage for the dry season and improving feed conservation and storage practices to avoid wastage of feed

- Allocating some irrigable land for irrigated forage production

- Producing and using hydroponic forage crops

- Availing credit facilities for feed production and purchase e.g. for purchase of agro-industrial byproducts.

- Integrating feed processing and distribution with dairy processing units (DPU) and milk collection services

In this regard, different actors including the government, nongovernmental organizations (NGOs) and the private sector could play different roles to enhance feed production, distribution and utilization efficiencies. The government is expected to encourage private investment in animal feed production and processing and provide capacity building/training and extension services. This could include, among others, availing agricultural investment incentive packages to private investors engaged in commercial forage and forage seed production as well as in feed production and processing businesses. Government support could include technical and advisory support, training and awareness creation, organizing farmer and youth groups of forage and forage seed producers, facilitation of credit services and provision of policy support to enhance feed production and the livestock sector development. The government may also make fair allocation of available land such as communal land for forage production. 
The NGOs can play vital roles in facilitating the organization of farmer and youth groups for forage and forage seed production, creating seed market linkage and provision of technical training. The roles of the private sector include timely supply of inputs, fair pricing of their products and services, availing sustainable supply of different variety of forage seeds and other feeds and improving the quality of feed they supply to livestock producers. In addition, other actors such the farmers' cooperatives and unions are expected to facilitate feed and seed supply.

\subsection{Purchase of additional feed from outside}

Some farmers buy additional feed mostly during the dry season (January - June) but some farmers buy throughout the year because of shortage of land and inability to produce sufficient feed for their animals. The extent to which farmers engage in purchase of additional feed depends on severity of feed shortage on the farm, production objective and degree of market orientation of the farm, and financial capacity of the farmer. However, the months when feed is purchased may vary from one farmer to another depending upon comparative availability of other feed resources on the different farms. Some farmers reported buying feed from January to September while others claimed that they buy from January to June while still some other farmers claimed that they buy additional feed throughout the year. The different types of feeds purchased by the farmers are given in Figure 4 .

The feeds commonly purchased by farmers in some districts of Oromia Regional State include agroindustrial by-products such as noug (Guizotia abyssinica) seed cake and wheat bran, dairy concentrate, atela, Desho grass and straw. The most common feeds purchased by the farmers in Fogera district of South Gondar zone, Amhara Regional State, include noug cake, wheat bran, rice bran, dairy concentrate, atela and hay. Some of the feeds such as straws and hays are purchased from individuals or other farmers. The brewers' grain purchased in Tigray region is obtained from Raya brewery. Atela is sourced from home brewing and distilling of locally consumed beverages like tella and areqe, respectively. Wheat bran may be purchased from flour mills. Traders play important roles as suppliers of most of the purchased feeds while cooperative unions may also supply some feeds. Table 18 shows the types and price of feed purchased by some of the respondents from selected districts.

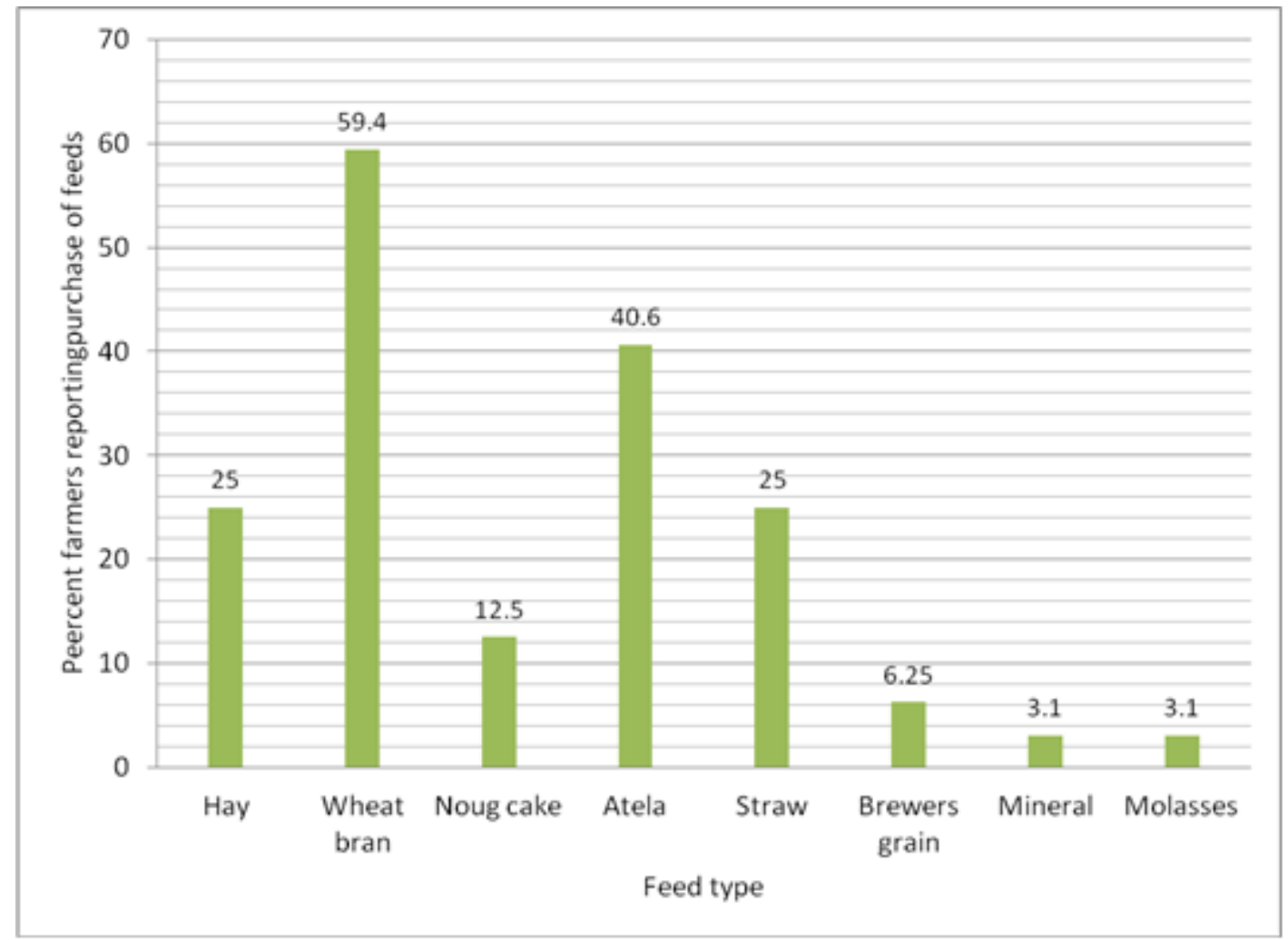

Figure 4 Percentage of farmers purchasing different types of feeds in Tigray regional state 
Table 18 Types and price (Birr/Quintal) of feed purchased by the respondents from different sites.

\begin{tabular}{lllll} 
Type of feed & Tigray & Oromia & Amhara (Fogera) & Amhara (Awabel) \\
Hay & $400-500$ & & 300 & $40-300$ \\
\hline Wheat bran & $700-800$ & 600 & 600 & 400 \\
\hline Noug cake & $650-850$ & $1700 ?$ & 400 & $600-780$ \\
\hline Concentrate & & 750 & 700 & 750 \\
\hline Rice bran & & 250 & 25 & \\
\hline Atela & $25-50$ & 250 & & \\
\hline Straw & $400-500$ & 200 & & \\
\hline Brewers grain & 150 & & & \\
\hline Molasses & 500 & 200 & &
\end{tabular}

\subsection{Selection of forage seeds and planting materials}

The type of forage seeds and/or planting materials supplied to each farmer depended on the advice of the project and government extension staff and for some of the forage crops on the interest of the farmers based on their previous acquaintance with some of the forage crops. Farmers in Arsi were reported to be happy with some of the forage crops such as Desho, oats-vetch but they were dissatisfied with some of the others such as alfalfa and fodder beet due to poor response. In Sidama zone, desho and elephant grass were selected by the farmers whereas the other forage crops were the recommendations of the SNV and the government extension staff. In general, the farmers in Sidama zone are not interested with forage crops that are propagated by seeds because of difficulty of reproducing by seeds more than once. For example, it is difficult to produce good quality and genuine seed of alfalfa. Thus, the farmers prefer forage crops that are propagated by cuttings as they are well aware of how to use the cuttings.

\subsection{Management of the established fodder crops.}

Different varieties of fodder crops require different management practices such as land preparation, fertilization, weeding, cutting or cropping frequency and techniques. The farmers plough the land once to three times before planting or sowing the forage crops depending upon the species. Most farmers also indicated that they apply manure or organic fertilizer to the forage land. They also reported that weeding of the forage plots have been accomplished from one to three times a year.

\subsection{Utilization and importance of improved forage crops}

All the farmers reported that they use all the forage they produce to feed their own animals. The forage is commonly used in cut-and-carry systems of feeding or as a green chop. Lactating dairy cows followed by calves, heifers, draught oxen and pregnant cows are given priority over other animals in feeding the improved forage crops. The amount of green forage fed per head of animal per day is very variable from farm to farm depending upon the amount of forage produced, and the number and production level of the animals kept on the farm. Farmers who produce very limited amount of forage can feed only about 1-3 kg of the forage as a supplement to other feeds. But farmers who keep high yielding crossbred dairy cows and cultivate forage crops on relatively wider area of land can provide larger quantity of the improved forge to their animals daily. Thus, some farmers reported providing about $10-30 \mathrm{~kg}$ of fresh forage per animal per day. The forages can be fed either separately or mixed with other feeds, which includes crop residues, hay, concentrates or other forage crop species. The respondents from Tigray region reported that hay or straw is mixed with forage crops in a $2: 1$ to $4: 1$ ratio of hay or straw: forages. 
All farmers in Degem primarily use the improved forages to feed to milking dairy cows and to less extent to calves. Most of the farmers mix the forages with other feeds such as crop residues whereas the remaining farmers feed separately or as sole feed. The farmers indicated that use of improved forages helped them to increase milk yield, body weight gain and body condition of their animals and reduced their feed cost by reducing the amount of concentrate feeds to be purchased from outside.

The production of cultivated forage crops is useful to improve the quantity and quality of feed supply. The impact of improved forages on feed cost depends upon the area of land planted to forage crops. The respondents indicated that the production and inclusion of improved forages in the diet of their animals may reduce feed cost by about $25 \%$ when the forage is planted on large plots of land. The farmers also reported that improved forages increase milk yield and body weight gain of their animals. Some farmers reported the use of the improved forage increase milk yield of dairy cows by about 5$50 \%$ when used as a supplement and by about $75-100 \%$ when fed as a sole diet. It was also reported that on-farm production and utilization of improved forages brings about significant reduction in feed cost. This is because of the fact that when adequate amount of good quality forage is supplied to the animals, the need for use of purchased concentrate or feeds derived from agro-industrial by-products will be substantially reduced or may not be necessary in some cases. However, the impact may not be visible when the forage is produced on very small plot of land. In situations where the dairy farm is far away from market centers and the price of milk is low, the opportunity cost of the land might be better for crop production than for forage production.

\subsection{Sustainability issues}

There are significant variations in the area of land allocated for forage production and the types and amount of forage produced from district to district and from farm to farm. This might be dictated by differences in land and livestock holdings of the farmers considered in the assessment. Despite such differences, all the respondents reported the benefits of the forage crops in terms of improving feed availability and quality, improving milk production of cows as well as body weight and body condition of animals and in reducing feed cost. The reduction in feed cost is mainly the cost saved because supply of good quality forage harvested from their backyard can reduce the quantity of dairy concentrates, hay and other feeds that the farmers may need to buy from outside. These findings are consistent with the EDGET project final evaluation report (EDGET, 2018). A few farmers also reported that they are able to generate income by selling forage seeds/splits to other farmers.

Some farmers have expanded their forage production activities as means producing good quality feed for their own animals and as a means of income generation through sale of forage seeds and/or planting materials. For example, about $50 \%$ of the respondents from Dale and Shebedino districts reported that they have multiplied the forage seeds and panting materials and thus currently have more area of planted forage than when the EDGET project started while about $25 \%$ of the respondents claimed to have maintained the same area of land as during the project period (i.e. no increase or decrease). Similarly, examples of farmers engaged in expanded and specialized production of Rhodes grass forage and seed and entering into seed marketing business has been cited as a notable success story from Dangila district of Awi Zone, Amhara Regional State.

Some farms reported a declining trend in the area of land planted to forage crops, which might be related to difficulty of getting sustainable supply of forage seeds/planting materials after the termination of the EDGET project or due to mere lack of motivation when the project support is not in place. On about $25 \%$ of farms in Dale and Shebedino districts, there was a decline in the area of land planted to forage after the end of the project due to management problem. Motivating farmers to produce, exchange and sell forage seeds and/or planting materials could contribute to the availability of forage seed/planting materials. However, for these farmers access to quality seed is essential for them to replenish fresh forage seed stocks over multiple years. They also need technical support to produce good quality seeds and there is a need for quality assurance system that rewards those who produce premium quality seed and that discourage poor quality seeds from entering the market. The farmers who produce good quality seeds also need dependable market linkage. 
Seed production of certain perennial forage crops is a complex process because different agronomic practices and special techniques of harvesting, threshing, and seed processing are required for different forage crops. The seed yield for most perennial grasses and herbaceous legumes is very small, usually within a range of $100-400 \mathrm{~kg} / \mathrm{ha}$. In addition to seed collection, the threshing and cleaning of the seeds of these perennial species are also difficult for many smallholder farmers because of requirements for special skills and knowhow. Annual forage crops require relatively simple management practices for seed production and exhibit higher productivity compared to the perennial ones.

Some farmers reported their readiness to continue with the production of the improved forage even after the termination of the project. Continuity would be much easier for forage crops multiplied by cuttings. Propagation by cuttings is much easier than use of seeds and the technique is more easily mastered by the farmers than the latter. Among the forage crops, oats is commonly grown in the central Ethiopian highlands and most farmers in the highlands have experience in its production and utilization, including seed production and marketing. A few farmers have also started producing the seeds of forage crops such as cow pea, lablab and pigeon pea. The production of the seeds of these forage crops is similar to food crops and relatively easy as compared other forage species.

Lack of well established and reliable markets and marketing system serves as disincentive that hinders engagement of most smallholder farmers in forage seed production as income generating activity. Moreover, there is paucity of information to clearly specify and articulate demand for forage seeds. The major buyers of forage seeds are NGOs and government institutions, which is not sustainable. Such uncertainty about market opportunities has a negative effect on engagement of smallholder farmers and the private sector in forage seed production for commercial purposes. One of the private forage seed producers in Ethiopia, Eden Field Agri-Seed Enterprise, indicated that about $98 \%$ of the forage produced by the company is sold to the government and NGOs. This indicates that there is limited demand for forage seeds from smallholder livestock keepers and the private sector. The fact that the government and NGOs buy and distribute the seeds to smallholder farmers for free has got a depressing effect on forage seed market development. Thus, more work has to be done to create market linkage and to balance demand for and supply of forage seeds to make the business viable for the involved actors. 
Ethiopia lacks either private or public forage seed production systems, which makes the seed system virtually nonexistent. In general, there is limited technical knowhow about forage seed production and management. In addition, there is no adequate information about seed quality and the country does not have seed certification system. The existing condition does not encourage the private sector and smallholder farmers to be engaged in forage seed production and marketing. So far, there is only one private sector operator in forage seed production with very limited capacity. This puts the country in sharp contrast with the neighbouring country, Kenya, which has much higher number of seed companies engaged for forage seed production and trade (SNV, 2013). The absence of formal forage seed system has created opportunities for market distortion and widespread marketing of poor quality seeds and seeds from unidentified sources by traders.

Sustainability of improved forage production depends on awareness of the farmers. The number of motivated farmers is limited. Urban and peri-urban dairy farmers who have access to land and those farmers who have access to irrigation would be in a better position to continue with improved forage production. However, the farmers need continuous follow up, technical support and market linkage to be active players in market oriented forage and livestock production. In addition, some kind of institutional set up for provision of basic and foundation seed would necessary to ensure sustainable seed supply. In this respect, it would be important to work closely with Regional Agricultural Research Institutes, the Ethiopian Institute of Agricultural Research (EIAR) and international agricultural research centres working on forage crops (e.g. ILRI and CIAT) for supply of basic seeds of the desired forage crops. In addition, it would be important to encourage interested private sector seed producers to produce the foundation seeds for wider multiplication with the involvement of smallholder farmers as out growers.

Government institutions and NGOs should stop providing free handout of forage seeds. The support of the government and NGOs should be towards creating a more sustainable seed system and this may include providing limited subsidy or partial financing to absorb the initial high cost of forage seeds where the farmers also make substantial contribution. The areas of support would be creation of market linkage and facilitation of credit services for those engaged in forage seed production and marketing. The government is also expected to develop a seed certification system to ensure the quality of the seed being marketed. 


\section{Conclusion and the way forward}

\subsection{Conclusion}

Livestock production is an important agricultural activity in all the study sites. However, the performance of the livestock resources is much below the potential because of several challenges constraining the productivity of livestock. Shortage of feed and low quality of the available feeds has often been cited as the main constraint. The major feed resources available in the country are crop residues and natural pastures while the production of cultivated forages is insignificant. Different species and variable quantities of forage seeds and planting materials were distributed to different farmers in selected districts of Amhara, Oromia and SNNP Regional states by SNV EDGET project and similar distribution was made in selected districts of Tigray region by Tigray Bureau of Agriculture and Natural Resources and Mekelle University. The aim was to improve the supply of good quality forage crops for dairy farmers in the selected districts and kebeles. The types and quantity of forage seeds/planting materials distributed to farmers and the area of land planted varied from place to place and from farm to farm depending on agro-ecology, area of land owned, livestock holding, which reflects demand for feed, and awareness and commitment of individual farmers. The quantity of seed given to individual farmers varied from 0.5 to $40 \mathrm{~kg}$ whereas the area of land planted to improved forage was in the range of $20 \mathrm{~m} 2$ to 3 ha.

However, sustainability of the intervention appears to be questionable in many cases while some farms have expanded the planting of forage crops. Free distribution of forage seeds by NGOs and government contributes to underdevelopment of the forage seed system. Sustainability depends on awareness of the farmers, availability of seeds/planting materials and dependable market linkage for forage/forage seed and livestock products. The farmers generally need continuous follow up for technical support and market linkage to be actively involved in cultivated forage and forage seed production.

\subsection{The way forward}

The following measures need to be taken to improve production and availability of cultivated forage crops to improve livestock feed supply.

1. Future forage development interventions should give more focus to forage crops that combine high yield potential with good nutritional quality to simultaneously address the problems of feed shortage and low quality of available feeds.

2. The government and development partners should give due attention and the necessary policy, technical and capacity building support for smallholder farmers and private sector actors interested in commercial forage and forage seed production

3. The smallholder farmers could be engaged in forage seed production and marketing either individually or organized into seed producers groups.

4. Creating market linkages for smallholder seed producers or linking the smallholder seed producers with commercial seed producers in out grower scheme for multiplication of forage seed on smallholder farms.

5. Providing training and the necessary technical support to the farmers to build their awareness and skills in improved forage production.

6. Arrangements for provision of basic and foundation seed would be necessary to ensure sustainable seed supply. In this respect, regional, national and international agricultural research centres working on forage crops could play important roles in basic seed supply, which can be linked with interested private sector seed producers for multiplication of the basic seeds to be used as a source of foundation seed. 
7. Government institutions and NGOs should stop providing free handout of forage seeds. Instead they may provide limited subsidy or partial financing to absorb the initial high cost of forage seeds through cost sharing arrangement with the farmers or seed producers.

8. The government is also expected to create favourable conditions for forage seed producers to access credit service or bank loan and to develop a seed certification system to ensure the quality of the seed being marketed. 


\section{$6 \quad$ References}

EARO (Ethiopian Agricultural Research Organization), 2000. Animal science research strategy. Animal sciences research Directorate, EARO, Addis Ababa, Ethiopia.

EDGET, 2018. EDGET Project Final Evaluation. March 2018.

FAO. 2004. Livestock Sector Brief. Livestock information sector analysis and policy branch. FAO, Rome SNV, 2013. Assessing the Situation of the Fodder Seed Supply Chain in Kenya. Fodder Sub-Sector Component of the "Kenya Market-led Dairy Programme" (KMDP).

Tolera, A., Assefa, G., Geleti, D., Gizachew, L. And Mengistu, A., 2012. Major Feed Resources. In: Tolera, A., Yami, A. and Alemu, D. (Eds.). Livestock Feed Resources in Ethiopia: Challenges, Opportunities and the Need for Transformation. Ethiopian Animal Feed Industry Association, Addis Ababa 


\section{Appendix 1 Questionnaire to Assess Introduction and Distribution of Fodder Seeds and Planting Materials}

\section{General (Importance of Livestock Production and Feed Supply)}

1. How important is livestock production to your livelihood? $1=$ Very high; $2=$ high; $3=$ intermediate; 4 = low; 5 = very low

If response is high or very high, why is it so important

2. Livestock holding: How many heads of different animal species of different classes or categories do you keep? (Size of livestock holding by species of animals and classes within species)?

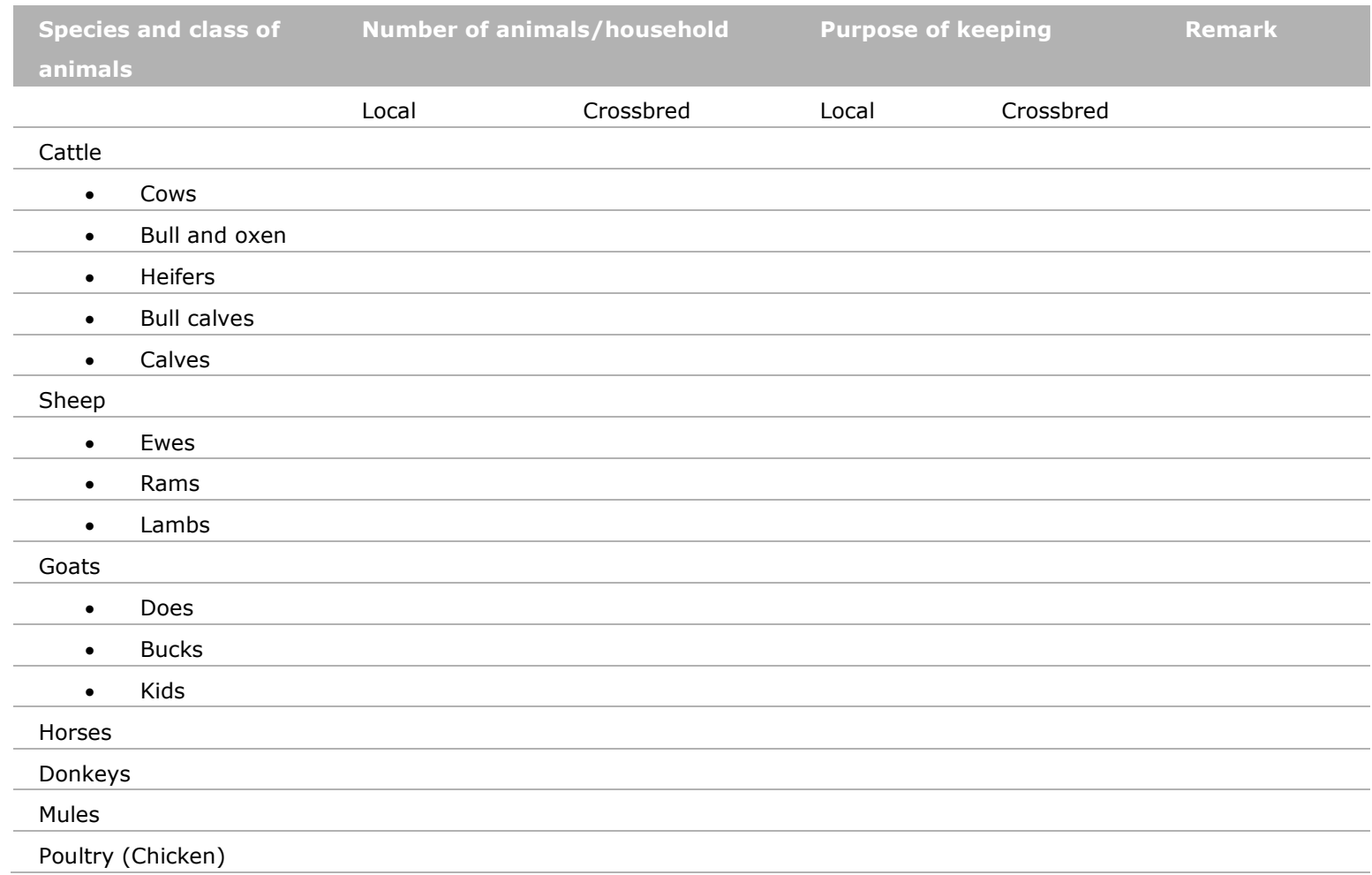

3. Have you observed any trends in livestock production over the last two to three decades in terms of species and number of animals kept per household (livestock holding per household) and regarding the productivity of the animals? If yes, what kind of trend have you observed? In your opinion, what are the possible causes for the observed trend?

\begin{tabular}{clcl}
\multicolumn{2}{l}{$\begin{array}{l}\text { Species and class of } \\
\text { animals }\end{array}$} & Trends in number of animals & Trends in productivity of animals \\
\multicolumn{1}{l|}{ Local } & Crossbred & Local & Crossbred \\
\hline Cattle & & & \\
\hline - & Cows & & \\
\hline - & Bull and oxen & Heifers & \\
\hline - & Bull calves & \\
\hline - & Calves & \\
\hline
\end{tabular}




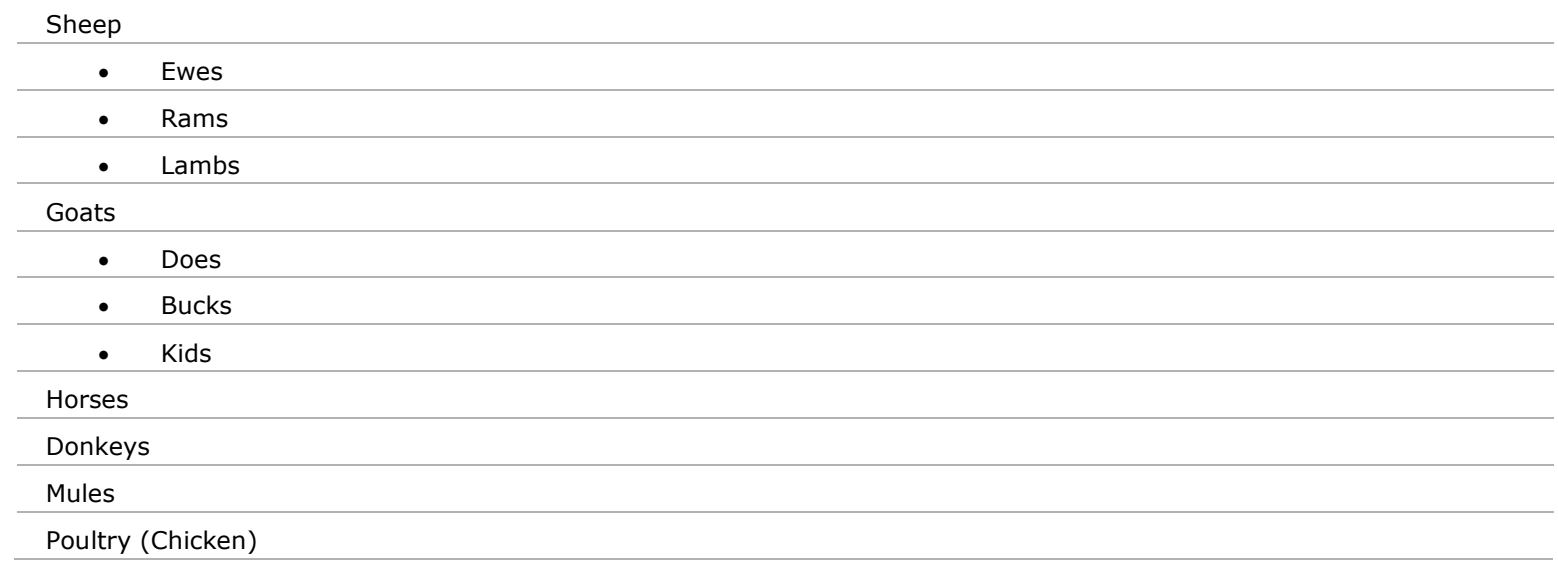

4. What are the main constraints that affect livestock production in your area, with decreasing order of importance?

5. How do you see the importance of feed in influencing livestock production and productivity?

6. Describe the types of feeds and feeding systems applied to different species and classes of animals during different seasons of the year.

\section{Improved forage production and use}

1. Do you grow improved forage crops for feeding your animals? If no, do you have any previous experience of growing forage crops? If yes, which species and varieties of forage crops?

2. How much forage do you produce each year? [area of land planted to forage (ha) and amount of forage produced $(\mathrm{kg})$ ]

3. Is the amount of forage you produce sufficient to feed your animals? If your answer is no, why?

4. What are the challenges you face to produce sufficient forage for your animals? If challenges are more than one, please list them in decreasing order of importance.

5. What will you do to alleviate the livestock feed problem in the future?

6. In your opinion, what should the following actors do to support the livestock feed sub-sector in general and improved forage production in particular?

a. governmental development and research organizations

b. non-governmental organizations

c. private sector actors, and

d. others, specify

7. Do you buy or sell any type of feed? $1=$ Yes I buy; $2=$ Yes I sale; $3=$ No, I do not buy or sale

8. If your answer to question No. 8 is yes I buy, which type of feed do you buy? When (in which months) do you buy? How much do you buy? What is the price per $\mathrm{kg}$ of feed? From whom do you buy?

9. If your answer to question No. 8 is yes I sale, which type of feed do you sale? When (in which months) do you sale? How much do you sale each year?

10. If your answer to question No. 8 is no, why?

\section{Introduction and distribution of fodder seeds and planting materials}


1. Have you received fodder seeds and/or planting materials distributed by SNV Edget Project/Tigray Bureau of Agriculture and Mekelle University?

2. Are there any other organizations that distributed forage seeds and planting materials in the area? If yes, which organizations?

3. Were there any pre-conditions or conditions you were expected to fulfill in order to qualify to receive the seed and or planting materials? If yes, what were the pre-conditions or conditions?

4. Can you tell us the type and amount of fodder seed $(\mathrm{kg})$ or planting material (number of cuttings) you received?

\begin{tabular}{lllllll} 
Forage species & Forage seed $(\mathrm{kg})$ & & \multicolumn{3}{l}{ Planting materials (number of } & Remark \\
& & & & & cuttings \\
& 2007 & 2008 & 2009 & 2007 & 2008 & 2009 \\
\hline
\end{tabular}

5. What were the criteria for selection of the type of fodder seed or planting materials? How was that decided? Who made the decision? Are you happy with the choice?

6. Do you have prior experience growing the same or similar types of fodder crops? If your answer is no, did you receive some kind of training or awareness creation how to establish, manage and use the forage crops? What kind of training (theoretical and/or practical) and for how long (day)? Who provided the training?

7. What is the area of land planted to the fodder seed or planting material received from the project?

\begin{tabular}{|c|c|c|c|c|c|c|}
\hline \multirow[t]{2}{*}{ Forage species } & \multicolumn{3}{|c|}{ Forage established from seed (ha) } & \multicolumn{3}{|c|}{ Forage established from cuttings (ha) } \\
\hline & 2007 & 2008 & 2009 & 2007 & 2008 & 2009 \\
\hline
\end{tabular}

What is the current area (ha)? If there is a difference between the area of land initially planted and the current area, what is the cause of the discrepancy?

8. How did you establish and manage the forage crops? Explain management practices related to land preparation, soil fertilization, weeding, cutting frequency etc.

\section{Utilization of the established forage}

1. What did you do with the established forages? $1=$ used as feed for own animals; $2=$ sold to other farmers or livestock keepers to generate income; $3=$ used part of it for own animals and sold the excess to others

2. How did you use the established forage? $1=$ in-situ grazing; $2=$ green chopping or cut-and-carry feeding fresh; $3=$ conserved as hay for dry season feeding 
3. Which species and class of animals are given priority in feeding the cultivated forages? Why?

4. How much of the improved forage (kg DM basis) do you feed to each animal per day? Do you use it as a sole feed or mix it with other feeds? If mixed with other feeds, with which types of feeds? What proportion of the total diet does it make?

5. What is the influence of your use of improved forages on

a. Productivity of your animals? Tell us the percent increase in milk yield or body weight gain or body condition of your animals because of inclusion of the improved forage.

b. Your feed cost? Tell us the percent reduction in your feed cost because of inclusion of the improved forage.

\section{Checklists for key informants}

1. What is your opinion about livestock feed situation with specific emphasis on improved forage production in this district?

2. Are there suppliers of forage seeds and planting materials?

3. How is the supply and demand of forage seeds and planting materials?

4. Are there any challenges associated with improved forage production and use? If yes, what?

5. Is there any certification of forage seeds? How is the quality guaranteed?

6. What can you to regulate the quality of the seed traded?

7. How is the market linkage?

8. What is your recommendation to improve the forage development and livestock feed supply? 

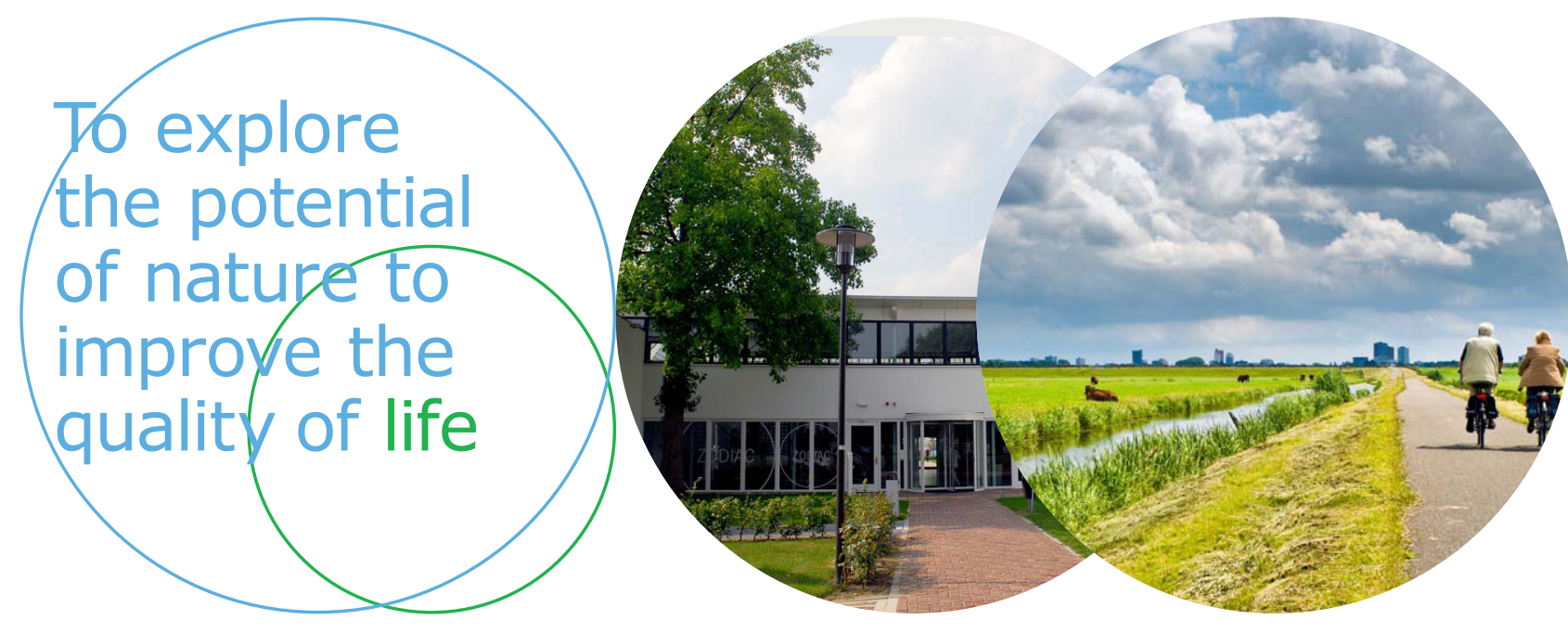

Wageningen Livestock Research P.O. Box 338

6700 AH Wageningen

The Netherlands

$\mathrm{T}+31(0) 317483953$

E info.livestockresearch@wur.nl

www.wur.nl/livestock-research

Wageningen Livestock Research creates science based solutions for a sustainable and profitable livestock sector. Together with our clients, we integrate scientific knowledge and practical experience to develop livestock concepts for future generations.

Wageningen Livestock Research is part of Wageningen University \& Research. Together we work on the mission: 'To explore the potential of nature to improve the quality of life'. A staff of 6,500 and 10,000 students from over 100 countries are working worldwide in the domain of healthy food and living environment for governments and the business community-at-large. The strength of Wageningen University \& Research lies in its ability to join the forces of specialised research institutes and the university. It also lies in the combined efforts of the various fields of natural and social sciences. This union of expertise leads to scientific breakthroughs that can quickly be put into practice and be incorporated into education. This is the Wageningen Approach. 